AperTO - Archivio Istituzionale Open Access dell'Università di Torino

\title{
Homo- and Hetero-oxidative Coupling of Benzyl Anions
}

\section{This is the author's manuscript}

Original Citation:

\section{Availability:}

This version is available http://hdl.handle.net/2318/1507538

since 2018-01-16T18:12:59Z

Published version:

DOI:10.1021/jo3000805

Terms of use:

Open Access

Anyone can freely access the full text of works made available as "Open Access". Works made available under a Creative Commons license can be used according to the terms and conditions of said license. Use of all other works requires consent of the right holder (author or publisher) if not exempted from copyright protection by the applicable law. 


\title{
Homo- and Hetero-Oxidative Coupling of Benzyl Anions
}

\author{
Marco Blangetti, Patricia Fleming and Donal F. O'Shea* \\ School of Chemistry and Chemical Biology, University College Dublin, Belfield, Dublin 4, \\ Ireland \\ Email: donal.f.oshea@ucd.ie
}

\section{TOC Graphical Abstract}

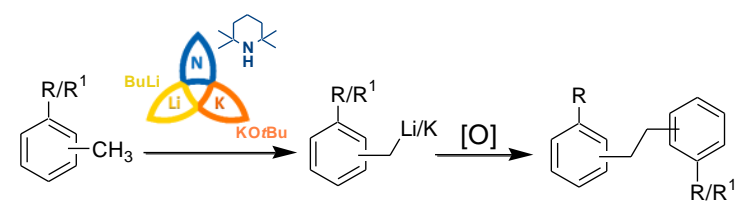

\begin{abstract}
The regioselective benzylic metalation of substituted toluenes using $\mathrm{BuLi} / \mathrm{KO} t \mathrm{Bu} / \mathrm{TMP}(\mathrm{H})$ (LiNK metalation conditions) with subsequent in situ oxidative $\mathrm{C}-\mathrm{C}$ coupling has been developed for the facile generation of 1,2-diarylethanes. A range of oxidants can be used for the oxidative coupling step, with 1,2-dibromoethane proving optimal. Heterocouplings can be achieved starting from a mixture of two different toluenes with a bias towards cross coupling achievable by using a two-fold excess of one toluene starting material. The utility of this approach is illustrated by the synthesis of several biologically active natural products. A distinct advantage is that the synthetic steps typically required to pre-activate the coupling substrates are eliminated and no transition metal is required to facilitate the $\mathrm{C}-\mathrm{C}$ bond formation.
\end{abstract}




\section{Introduction}

The repertoire of carbon-carbon bond formation reactions utilizing oxidative coupling, while limited, continues to expand. ${ }^{1}$ As might be expected, the majority of these transformations are transition metal catalyzed but some transition metal free variants have been accomplished. Recent examples include the coupling of Grignard reagents using TEMPO or 3,3',5,5'-tetra-tbutyldiphenoquinone as oxidants. ${ }^{2}$ As oxidative $\mathrm{C}-\mathrm{C}$ coupling requires the combining of two carbon nucleophiles, this approach would have enhanced synthetic efficiency if the nucleophiles could be generated via a direct $\mathrm{C}-\mathrm{H}$ deprotonation of readily available inexpensive starting substrates and the oxidative coupling could be achieved without a transition metal.

We have recently described use of the reagent triad $\mathrm{BuLi} / \mathrm{KO} t \mathrm{Bu} / \mathrm{TMP}(\mathrm{H})$ ( $\mathrm{LiNK}$ metalation) to in situ generate a mixed Li/K metal TMP amide as a general method for benzylic metalations with excellent selectivity. ${ }^{3}$ We now report the use of this benzylic metalation strategy in tandem with an in situ oxidative coupling for $\mathrm{Csp}^{3}-\mathrm{Csp}^{3}$ bond formation. ${ }^{4}$ Oxidative homo-coupling of benzyl anions has previously been noted, but it has remained relatively unexplored as a synthetic procedure. 5

\section{Results and Discussion}

Prior to this study, we first established the regioselectivity of LiNK metalation of toluene by its treatment with 1.2 equiv. of $\mathrm{BuLi} / \mathrm{KO} t \mathrm{Bu} / \mathrm{TMP}(\mathrm{H})$ in $\mathrm{THF}$ at $-78{ }^{\circ} \mathrm{C}$ and quenching with $\mathrm{CD}_{3} \mathrm{OD}$ (Scheme 1). ${ }^{1} \mathrm{H}$ and ${ }^{2} \mathrm{H}$ NMR analysis of the product showed that deuterium $(73 \% \mathrm{D})$ was solely incorporated into the benzylic position with no aryl deuterium observed, confirming that organometallic $2 \mathbf{a}$ could be selectively generated (Scheme 1). The apparent simplicity of this metalation belies the fact achieving this deprotonation with compete selectivity without the use of an excess of toluene at elevated temperatures can be challenging. ${ }^{6}$ The ability of LiNK metalation conditions to provide routine low temperature access to the thermodynamically favored benzyl anion prompted us to combine this with a tandem oxidative $\mathrm{C}-\mathrm{C}$ bond forming strategy. 
Scheme 1. Selective benzylic metalation of toluene

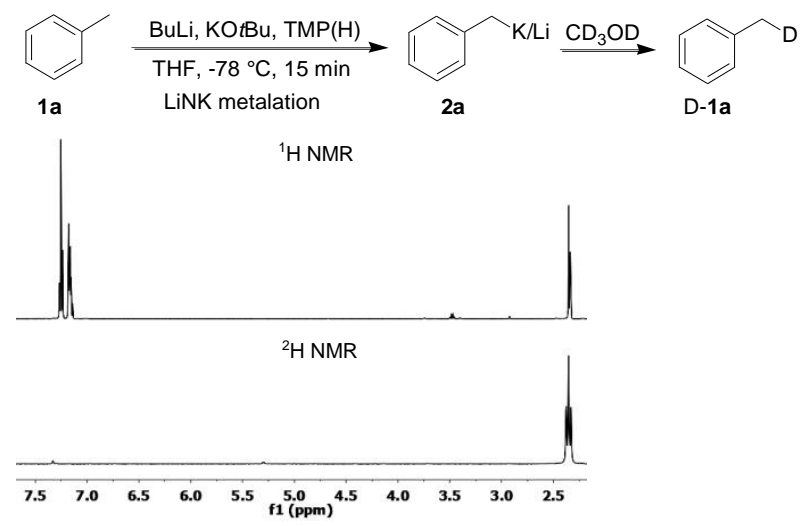

Having established our metalation approach could selectively provide 2a, a variety of oxidants were examined to achieve its homo-coupling to 1,2-diphenylethane 3a (Table 1). Encouragingly, treatment of $2 \mathbf{a}$ at $-78{ }^{\circ} \mathrm{C}$ for 5 minutes with oxygen, ceric ammonium nitrate (CAN) or iodine all gave the coupled product 3a in 62,35 , and $47 \%$ yields respectively (Table 1, entries 1-3). The inexpensive oxidant 1,2-dibromoethane proved optimal giving a product yield of $71 \%$ (entry 4). ${ }^{7}$ In this case oxidative coupling occurred immediately upon addition of dibromoethane based upon the disappearance of the characteristic organometallic color. Interestingly, when TEMPO was used as oxidant at $-78{ }^{\circ} \mathrm{C}$ and the reaction worked up after 5 minutes, only a trace of 3a was observed. Yet, upon warming the reaction to $\mathrm{rt}$ for $2 \mathrm{~h}$, coupling product was efficiently formed in a 58\% yield. In comparison, benzyl magnesium chloride was also examined for its ability to oxidatively couple with dibromoethane. No reaction was found to occur at $-78{ }^{\circ} \mathrm{C}$ yet upon reaction for $2 \mathrm{~h}$ at $\mathrm{rt}$ a $81 \%$ yield of $\mathbf{3 a}$ was obtained (entries 7,8 ). This shows a general ability of benzylic organometallics to undergo transition metal free oxidative couplings with the enhanced low temperature reactivity of 2a versus the Grignard attributable to the more ionic character of 2a. While the exact mechanism of the dibromoethane mediated coupling of $2 \mathbf{a}$ is as of yet unknown, two general possibilities could be envisaged. The first being the one electron oxidation of 2a by dibromoethane with subsequent dimerization to 3a. Alternatively bromination of $\mathbf{2 a}$ by dibromoethane could form benzyl bromide which could generate 3a by in situ reaction with unreacted 2a. As oxygen is capable of oxidizing 2a to produce 3a this mechanism could be 
viable with dibromoethane as it is a known oxidant. But to illustrate that bromination/coupling pathway coul also be in operation treatment of $\mathbf{2 a}$ with benzylbromide did also produce 3a.

Table 1. LiNK metalation and oxidative coupling of toluene

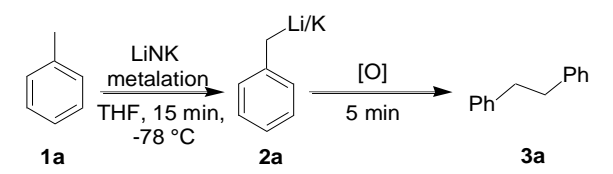

\begin{tabular}{|c|c|c|c|c|}
\hline entry & substrate & oxidant & temp $/{ }^{\circ} \mathrm{C}$ & 3a yield $\%^{\mathrm{a}}$ \\
\hline 1 & 1a & $\mathrm{O}_{2}$ & -78 & 62 \\
\hline 2 & $1 \mathbf{a}$ & CAN & -78 & 35 \\
\hline 3 & $1 \mathbf{a}$ & $\mathrm{I}_{2}$ & -78 & 47 \\
\hline 4 & $1 \mathbf{a}$ & $\mathrm{Br}\left(\mathrm{CH}_{2}\right)_{2} \mathrm{Br}$ & -78 & 71 \\
\hline 5 & $1 \mathbf{a}$ & TEMPO & -78 & trace \\
\hline 6 & $1 \mathbf{a}$ & TEMPO & $\mathrm{rt} / 2 \mathrm{~h}$ & 58 \\
\hline 7 & $\mathrm{PhCH}_{2} \mathrm{MgCl}$ & $\mathrm{Br}\left(\mathrm{CH}_{2}\right)_{2} \mathrm{Br}$ & -78 & 0 \\
\hline 8 & $\mathrm{PhCH}_{2} \mathrm{MgCl}$ & $\mathrm{Br}\left(\mathrm{CH}_{2}\right)_{2} \mathrm{Br}$ & $\mathrm{rt} / 2 \mathrm{~h}$ & $81^{\mathrm{b}}$ \\
\hline
\end{tabular}

The generality of this metalation/coupling method was next examined for a series of substituted toluene derivatives. The reaction sequence proved very general and tolerant of fluoro, amino, carboxy, ether and amido functional groups in ortho, meta and para positions relative to the methyl group (Table 2, entries 1-8). Di and tri-substituted toluenes and xylenes were also successfully dimerized in good yields (entries 9-10). Of particular note is the hexa-methoxylated natural product brittonin A 3k which can be synthesized with $69 \%$ yield in a single step (Table 2, entry 11$){ }^{8}$ 
Table 2. Homo-oxidative coupling of substituted toluenes

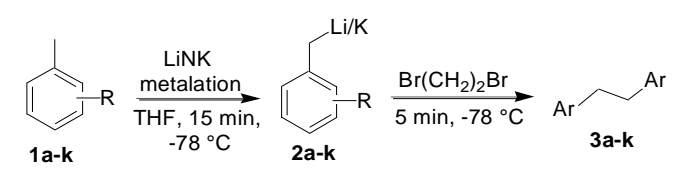

\begin{tabular}{lllll}
\hline entry & subst. & R & product & yield $(\%)^{\mathrm{a}}$ \\
\hline 1 & $\mathbf{1 a}$ & $\mathrm{H}$ & $\mathbf{3 a}$ & 71 \\
2 & $\mathbf{1 b}$ & $2-\mathrm{F}$ & $\mathbf{3 b}$ & 78 \\
3 & $\mathbf{1 c}$ & $2-\mathrm{NMe}_{2}$ & $\mathbf{3 c}$ & 58 \\
4 & $\mathbf{1 d}$ & $2-\mathrm{CO}_{2} \mathrm{H}$ & $\mathbf{3 d}$ & 53 \\
5 & $\mathbf{1 e}$ & $2-\mathrm{OMe}$ & $\mathbf{3 e}$ & 63 \\
6 & $\mathbf{1 f}$ & $3-\mathrm{OMe}$ & $\mathbf{3 f}$ & 68 \\
7 & $\mathbf{1 g}$ & $3-\mathrm{OMOM}$ & $\mathbf{3 g}$ & 46 \\
8 & $\mathbf{1 h}$ & $4-\mathrm{CON} i \mathrm{Pr}$ & $\mathbf{3 h}$ & 83 \\
9 & $\mathbf{1 i}$ & $3,5-(\mathrm{OMe})_{2}$ & $\mathbf{3 i}$ & $80^{\mathrm{b}}$ \\
10 & $\mathbf{1 j}$ & $2-\mathrm{OMe}-4-\mathrm{Me}$ & $\mathbf{3 j}$ & 88 \\
11 & $\mathbf{1 k}$ & $3,4,5-(\mathrm{OMe})_{3}$ & $\mathbf{3 k}$ & 69 \\
a $y i e l d$ & refers to isolated product. ${ }^{\mathrm{b}}$ substrate added to a premixed solution \\
of BuLi/KOtBu/TMP(H).
\end{tabular}

In an effort to optimize conditions for hetero-couplings, toluene 1a and 3-methylanisole 1f were used as test substrates (Table 3). It was found that metalation and oxidative coupling of a 1:1 ratio of each substrate gave a $24 \%$ yield of hetero-dimer 4 a following chromatographic separation from the two homo-dimers 3a (25\%) and $\mathbf{3 f}(19 \%)$. This yield could be improved to $41 \%$ if a 2:1 ratio of 1a:1f was used and a comparable yield was obtained if the ratio was reversed with an excess of $\mathbf{1 f}$ employed (Table 3, entries 2 and 3). 
Table 3. Hetero-oxidative coupling of toluenes

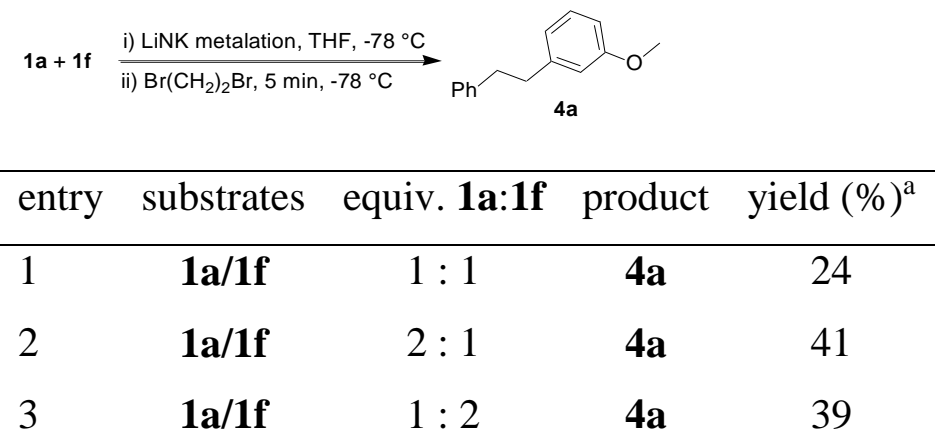

${ }^{a}$ yield refers to isolated product based on limiting reagent.

While complete selectivity for $\mathbf{4 a}$ was not achieved, this single step approach from the simplest toluene starting materials remains favorable if alternative multi-step routes are considered. For example, alternative multi-step approaches to $\mathbf{4 a}$ would require synthesis of suitably functionalized starting substrates such as; benzyl phosphonium ylide and aryl aldehyde for Wittig olefination followed by alkene reduction. ${ }^{9}$ This approach requires five individual reactions from toluene starting materials and the use of a transition metal catalyst (i.e. oxidation of one toluene substrate to its aromatic aldehyde, bromination of the other toluene substate to its benzyl bromide, conversion to its phosphonium salt, Wittig olefination and alkene reduction) versus one for the heterooxidative coupling with no transition metal required. Other alternative multi-step approaches include the Pd catalyzed coupling of 2-phenylethyltrifluoroborate and arylbromide and arylzinc chloride and triphenylethanyl indium. ${ }^{10,11}$

1,2-Diarylethane (bibenzyl) is a particularly common natural product scaffold isolated from numerous plants such as liverwort and orchids. ${ }^{12}$ Use of these plants has a long history in traditional medicine and ongoing analysis of individual extracted bibenzyls has shown diverse biological activities including antifungal, antimicrobial, antioxidant, anti-proliferative and multidrug resistance reversal properties. Typical substituent patterns for this natural product class include varying degrees of methoxy or phenolic substituents on the aromatic rings. Exploiting our cross-coupling approach, it was possible to synthesize numerous examples of these natural products in a single synthetic operation (Table 4).

Compound $\mathbf{4 b}$ was synthesized in a $43 \%$ yield from toluene and 3-OMOM-toluene 1g. Acidic deprotection to 3-phenethylphenol $\mathbf{4 c}$ was readily achieved providing the phenolic substituted 
natural product 4c. ${ }^{13}$ Oxidative cross-coupling of toluene was equally successful with 3,5dimethoxytoluene and 3,4,5-trimethoxytoluene, to give natural products $\mathbf{4 d}$ and $\mathbf{4 e}$ (entries 3, 4). ${ }^{14}$ Similarly, the tri- and tetra-methoxy substituted bibenzyls $\mathbf{4 f}$ (batatasin III dimethylether) and $\mathbf{4 g}$ (aloifol I dimethylether) were obtained in 58 and 52\% yields from 3-methoxytoluene with $\mathbf{1 i}$ and $\mathbf{1 k}$ respectively. ${ }^{15}$

Table 4. Synthesis of ether and phenolic substituted 1,2-diarylethane (bibenzyl) natural products

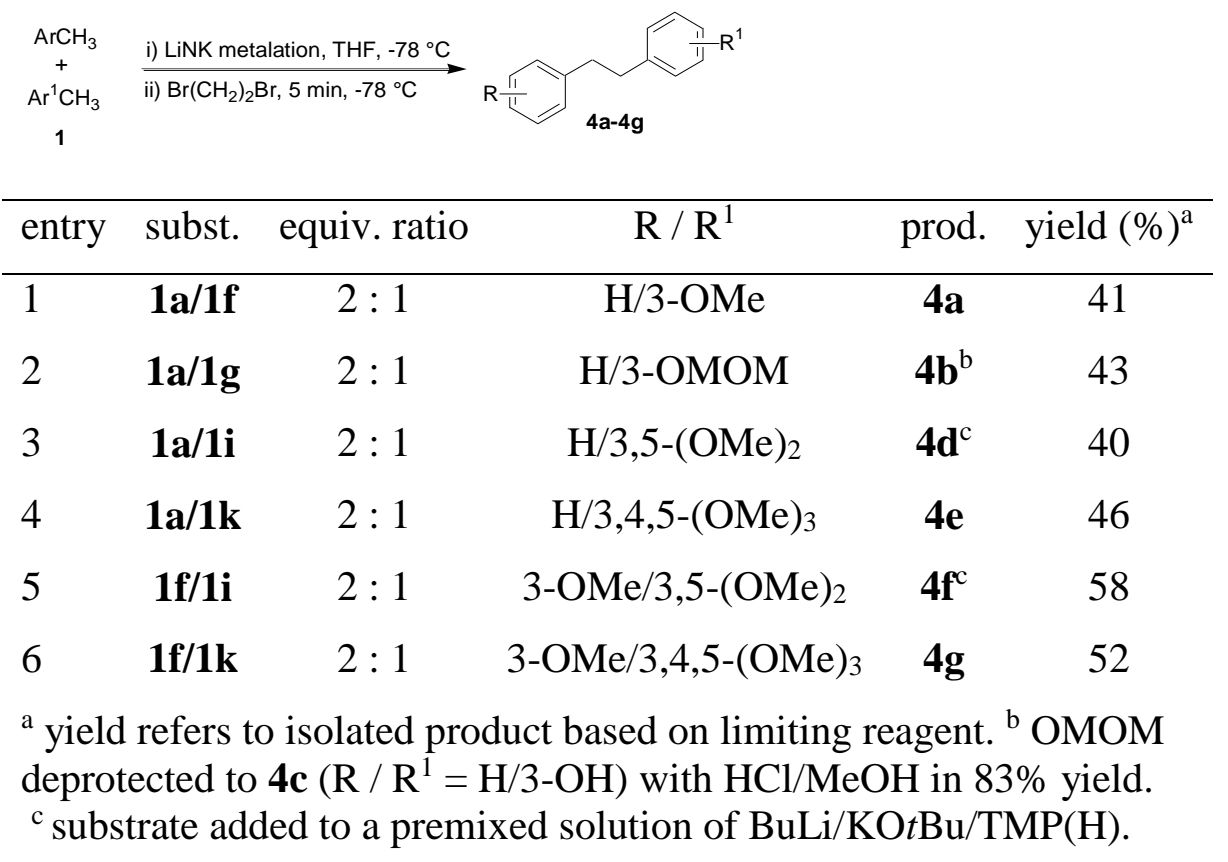

The synthesis of stilbostemin M 6, stilbostemin B 7 and bauhinol D 8 from 1,3-dimethoxy-5methylbenzene 1i provided an illustration of how the complementary metalation selectivity achievable with classic super-base conditions of $\mathrm{BuLi} / \mathrm{KO} t \mathrm{Bu}^{16}$ and LiNK $(\mathrm{BuLi} / \mathrm{KO} t \mathrm{Bu} / \mathrm{TMP}(\mathrm{H})$ ) can be exploited for targeted synthesis (Scheme 2). As described above the benzylic metalation of $\mathbf{1 i}$ under LiNK conditions could be used for synthesis of natural product 4d (Table 4, entry 3). In contrast, selective kinetic metalation of $\mathbf{1 i}$ at the C-2 aryl position (between the two methoxy groups) with $\mathrm{BuLi} / \mathrm{KO} t \mathrm{Bu}$ was confirmed by deuteration and exploited for the synthesis of 1,3-dimethoxy-2,5-dimethylbenzene 5 by reaction with methyl iodide (Scheme 2). Substrate 5 presents an elevated selectivity challenge for a LiNK metalation as it contains two non-equivalent methyl groups with oxidative coupling at the 5-methyl required for the natural product syntheses. As we have previously shown, it could be anticipated, based 
upon relative $\mathrm{CH}$ acidities of both methyl groups, that this could be achieved. ${ }^{3 a}$ The desired 5methyl selectivity was confirmed by ${ }^{2} \mathrm{H}$ NMR product analysis following LiNK metalation and treatment with $\mathrm{CD}_{3} \mathrm{OD}$, with the spectrum showing one triplet corresponding to D-5 and no aryl deuteration (Scheme 2, supporting information). With the desired regioselective metalation established, oxidative cross-coupling of $\mathbf{5}$ with toluene gave stilbostemin $\mathrm{M}$ in a $41 \%$ yield. Demethylation of $\mathbf{6}$ with $\mathrm{BBr}_{3}$ gave the corresponding diphenol natural product 7, stilbostemin $\mathrm{B}$, which has been shown to be a biologically active isolate from the roots of Stemona japonica and Stemona tuberosa and has numerous cited uses in Chinese medicine. ${ }^{17}$ In addition to being natural products in themselves, the bibenzyls we have described are common intermediates in the synthesis of prenyl and pyranyl, furan and glycoside substituted analogues. ${ }^{18}$ For example, conversion of 7 into bauhinol D 8 by ethylenediaminediacetate (EDDA) catalyzed reaction with 3-methyl-2-butenal has recently been shown. ${ }^{19}$

Scheme 2. Synthesis of stilbostemin M 6, stilbostemin B 7 and bauhinol D 8.

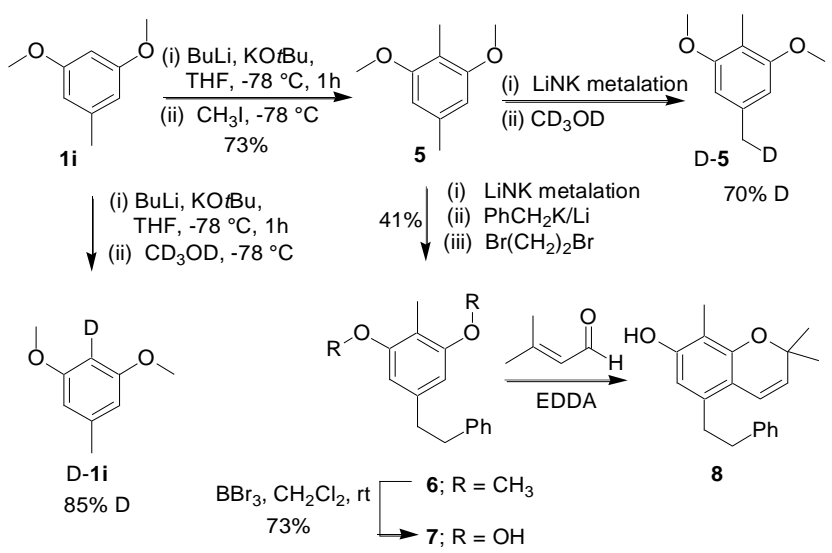

\section{Conclusion}

In summary, regioselective benzylic metalation with $\mathrm{BuLi} / \mathrm{KO} t \mathrm{Bu} / \mathrm{TMP}(\mathrm{H})$ can be used in conjunction with 1,2-dibromoethane mediated oxidative coupling to allow direct access to the bibenzyl scaffold. This one-pot synthetic operation from toluene starting materials allows easy access to this biologically important natural product class without requiring additional synthetic steps to pre-activate the coupling partners or the use of a transition metal catalyst. A distinct advantage is that the synthetic steps typically required to pre-activate the coupling toluene 
substrates are eliminated thereby dramatically reducing the number of synthetic step. Further synthetic applications utilizing LiNK metalation are under development and will be reported in due course.

\section{Experimental}

General Methods. All reactions involving air-sensitive reagents were performed under nitrogen in oven-dried glassware using syringe-septum cap technique. All solvents were purified and degassed before use. Unless it is specified, all reagents were used as received without further purifications. TMP was distilled from $\mathrm{CaH}_{2}$ prior to use and THF was obtained from a solvent purification system. BuLi was purchased as a $2.5 \mathrm{M}$ solution in hexanes. $\mathrm{KO} t \mathrm{Bu}$ was purchased as a $1 \mathrm{M}$ solution in THF. The exact concentration of the organolithium solution was determined by titration with diphenylacetic acid in THF prior to use. ${ }^{20}$

Deuteriomethylbenzene (D-1a). ${ }^{21}$ A solution of toluene $1 \mathbf{a}(1.00 \mathrm{~mL}, 9.38 \mathrm{mmol})$ in THF $(5 \mathrm{~mL})$ at $-78{ }^{\circ} \mathrm{C}$ was treated dropwise with BuLi $(2.50 \mathrm{M}, 4.50 \mathrm{~mL}, 11.20 \mathrm{mmol})$ and stirred for $5 \mathrm{~min}$. $\mathrm{KO} t \mathrm{Bu}(1.0 \mathrm{M}$ in THF, $11.20 \mathrm{~mL}, 11.20 \mathrm{mmol})$ was added dropwise followed by 2,2,6,6tetramethylpiperidine $(1.60 \mathrm{~mL}, 9.38 \mathrm{mmol})$. The reaction mixture was stirred for $1 \mathrm{~h}$ at $-78{ }^{\circ} \mathrm{C}$ and $\mathrm{CD}_{3} \mathrm{OD}(0.60 \mathrm{~mL})$ added. The reaction mixture was allowed to warm to room temperature and portioned between diethyl ether $(30 \mathrm{~mL})$ and water $(30 \mathrm{~mL})$. The organic layer was washed several times with water, and the combined organic extracts were dried over magnesium sulphate and distilled with a fractionating column. The fraction boiling between 110 and $115{ }^{\circ} \mathrm{C}$ was collected to give D-1a as a colorless oil (73\% D incorporation). $\left.{ }^{1} \mathrm{H} \mathrm{NMR} \mathrm{(500} \mathrm{MHz}, \mathrm{CDCl}_{3}\right): \delta$ 7.29-7.22 (m, 2H), 7.21-7.12 (m, 3H), 2.37-2.30 (m, 2H). ${ }^{13} \mathrm{C}$ NMR (125 MHz, $\left.\mathrm{CDCl}_{3}\right): \delta 137.8$, 129.0, 128.2, 127.3, 125.3, $21.1(\mathrm{t}, J=19.1 \mathrm{~Hz}) .{ }^{2} \mathrm{H} \mathrm{NMR}\left(92.07 \mathrm{MHz}, \mathrm{CH}_{2} \mathrm{Cl}_{2}\right): \delta 2.35(\mathrm{t}, J=$ $2.2 \mathrm{~Hz})$.

2-Deuterio-1,3-dimethoxy-5-methylbenzene (D-1i). A solution of 3,5-dimethoxytoluene 1i (121 $\mathrm{mg}, 0.80 \mathrm{mmol})$ in THF $(10 \mathrm{~mL})$ at $-78^{\circ} \mathrm{C}$ was treated dropwise with BuLi $(2.50 \mathrm{M}$ in hexanes, $0.35 \mathrm{~mL}, 0.88 \mathrm{mmol})$ and stirred for $5 \mathrm{~min}$. $\mathrm{KO} t \mathrm{Bu}(1.0 \mathrm{M}$ in $\mathrm{THF}, 0.88 \mathrm{~mL}, 0.88 \mathrm{mmol})$ was added dropwise, and the reaction mixture was stirred for $1 \mathrm{~h}$ at $-78^{\circ} \mathrm{C}$. Then $\mathrm{CD}_{3} \mathrm{OD}(0.20 \mathrm{~mL})$ was added, and the reaction mixture was stirred at $-78^{\circ} \mathrm{C}$ for an additional time of $5 \mathrm{~min}$. The reaction mixture was warmed to room temperature and the solvent removed under reduced pressure. Diethyl ether $(30 \mathrm{~mL})$ was added to the residue, washed with $\mathrm{HCl}(2 \mathrm{M}, 3 \times 10 \mathrm{~mL})$, 
dried over sodium sulphate and concentrated to dryness to give D-1i as a colorless oil (105 mg, 86\%, 85\% D incorporation). ${ }^{1} \mathrm{H}$ NMR (500 MHz, $\left.\mathrm{CDCl}_{3}\right): \delta 6.33$ (s, 2H), $3.77(\mathrm{~s}, 6 \mathrm{H}), 2.30(\mathrm{~s}$, 3H). ${ }^{13} \mathrm{C} \mathrm{NMR}\left(125 \mathrm{MHz}, \mathrm{CDCl}_{3}\right): \delta 159.7,139.2,106.1,96.5$ (bs), 54.2, 20.8. ${ }^{2} \mathrm{H}$ NMR (92.07 $\mathrm{MHz}, \mathrm{CH}_{2} \mathrm{Cl}_{2}$ ): $\delta 6.28$ (s). HRMS [M] $]^{+}: 153.0900, \mathrm{C}_{9} \mathrm{H}_{11} \mathrm{DO}_{2}$ requires 153.0900 .

5-(Deuteriomethyl)-1,3-dimethoxy-2-methylbenzene (D-5). A solution of 1,3-dimethoxy-2,5dimethylbenzene $5(75 \mathrm{mg}, 0.45 \mathrm{mmol})$ in THF $(10 \mathrm{~mL})$ at $-78{ }^{\circ} \mathrm{C}$ was treated dropwise with BuLi (2.50 M in hexanes, $0.20 \mathrm{~mL}, 0.50 \mathrm{mmol})$ and stirred for $5 \mathrm{~min}$. $\mathrm{KO} t \mathrm{Bu}(1.0 \mathrm{M}$ in $\mathrm{THF}$, $0.50 \mathrm{~mL}, 0.50 \mathrm{mmol})$ was added dropwise followed by 2,2,6,6-tetramethylpiperidine (76 $\mu \mathrm{L}$, $0.45 \mathrm{mmol})$. The reaction mixture was stirred for $15 \mathrm{~min}$ at $-78^{\circ} \mathrm{C}$ and $\mathrm{CD}_{3} \mathrm{OD}(0.20 \mathrm{~mL})$ added and stirred for a further $5 \mathrm{~min}$. The reaction mixture was warmed to room temperature and the solvent removed under reduced pressure. Diethyl ether $(30 \mathrm{~mL})$ was added to the residue, washed with $\mathrm{HCl}$ ( $2 \mathrm{M}, 3 \times 10 \mathrm{~mL})$, dried over sodium sulphate and concentrated to dryness to give D-5 as a colorless solid (65 mg, 86\%, 70\% D incorporation, mp. 48-49 $\left.{ }^{\circ} \mathrm{C}\right) .{ }^{1} \mathrm{H}$ NMR (500 $\left.\mathrm{MHz}, \mathrm{CDCl}_{3}\right): \delta 6.36(\mathrm{~s}, 2 \mathrm{H}), 3.80(\mathrm{~s}, 6 \mathrm{H}), 2.33-2.29(\mathrm{~m}, 2 \mathrm{H}), 2.05(\mathrm{~s}, 3 \mathrm{H}) .{ }^{13} \mathrm{C} \mathrm{NMR}(125 \mathrm{MHz}$, $\left.\mathrm{CDCl}_{3}\right): \delta 158.2,136.2,136.1,111.4,104.5,55.7,21.6(\mathrm{t}, J=19.4 \mathrm{~Hz}), 7.8 .{ }^{2} \mathrm{H}$ NMR $(92.07$ $\left.\mathrm{MHz}, \mathrm{CH}_{2} \mathrm{Cl}_{2}\right): \delta 2.31(\mathrm{t}, J=2.2 \mathrm{~Hz})$. HRMS [M] $]^{+}: 167.1055, \mathrm{C}_{10} \mathrm{H}_{13} \mathrm{DO}_{2}$ requires 167.1057.

General procedure for the optimization of homocoupling reaction. A solution of toluene 1a (46 mg, $0.50 \mathrm{mmol})$ in THF $(15 \mathrm{~mL})$ at $-78{ }^{\circ} \mathrm{C}$ was treated dropwise with BuLi (2.37 M, 0.25 $\mathrm{mL}, 0.60 \mathrm{mmol})$ and stirred for $5 \mathrm{~min}$. $\mathrm{KO} t \mathrm{Bu}(1.0 \mathrm{M}$ in THF, $0.60 \mathrm{~mL}, 0.60 \mathrm{mmol})$ was added dropwise followed by 2,2,6,6-tetramethylpiperidine $(84 \mu \mathrm{L}, 0.50 \mathrm{mmol})$. The reaction mixture was stirred for $15 \mathrm{~min}$ at $-78^{\circ} \mathrm{C}$, oxidant added and stirred for a further $5 \mathrm{~min}$. The reaction mixture was warmed to room temperature and the solvent removed under reduced pressure. Diethyl ether $(30 \mathrm{~mL})$ was added to the residue, washed with $\mathrm{HCl}(2 \mathrm{M}, 3$ x $10 \mathrm{~mL})$, dried over sodium sulphate and concentrated to dryness. Purification by silica gel chromatography eluting with 92:8 cyclohexane:diethyl ether gave 1,2-diphenylethane $\mathbf{3 a}$ as a colorless solid $\left(\mathrm{R}_{f}=0.80\right)$.

$\mathrm{O}_{2}$ (bubbling): $28 \mathrm{mg}, 62 \%$.

Ceric ammonium nitrate: (822 mg, $1.50 \mathrm{mmol}) .16 \mathrm{mg}, 35 \%$.

Iodine: (380 mg, $1.50 \mathrm{mmol}) .21 \mathrm{mg}, 47 \%$.

1,2-Dibromoethane: (0.13 mL, $1.50 \mathrm{mmol}) .32 \mathrm{mg}, 71 \%$.

TEMPO: (158 mg, $1.00 \mathrm{mmol})$. After the addition of TEMPO the reaction mixture was stirred for $2 \mathrm{~h}$ at room temperature. $26 \mathrm{mg}, 58 \%$. 


\section{Coupling reaction of benzylmagnesium chloride.}

1,2-Diphenylethane (3a). Benzyl chloride (60 $\mathrm{mg}, 0.47 \mathrm{mmol}$ ) was added dropwise to a stirred suspension of magnesium powder $(12 \mathrm{mg}, 0.50 \mathrm{mmol})$ in dry THF $(4 \mathrm{~mL})$, and the reaction mixture was refluxed under nitrogen. After $30 \mathrm{~min}$ the resulting Grignard reagent was cooled down to room temperature, and 1,2-dibromoethane $(0.13 \mathrm{~mL}, 1.50 \mathrm{mmol})$ was added. The reaction mixture was stirred for $2 \mathrm{~h}$, then quenched with water and extracted with diethyl ether (2 x $10 \mathrm{~mL}$ ). The combined organic layer was dried over sodium sulphate and concentrated to dryness. Purification by silica gel chromatography eluting with 92:8 cyclohexane:diethyl ether gave 1,2-diphenyethane 3a as a colorless solid (35 $\mathrm{mg}, 81 \%$ ).

\section{Coupling reaction of 2 a with benzyl bromide.}

1,2-Diphenylethane (3a). A solution of toluene 1a (92 mg, $1.00 \mathrm{mmol})$ in THF (15 mL) at -78 ${ }^{\circ} \mathrm{C}$ was treated dropwise with $\mathrm{BuLi}(2.37 \mathrm{M}, 0.51 \mathrm{~mL}, 1.20 \mathrm{mmol})$ and stirred for $5 \mathrm{~min} . \mathrm{KO} t \mathrm{Bu}$ (1.0 $\mathrm{M}$ in THF, $1.20 \mathrm{~mL}, 1.20 \mathrm{mmol}$ ) was added dropwise followed by 2,2,6,6tetramethylpiperidine $(0.17 \mathrm{~mL}, 1.00 \mathrm{mmol})$. The reaction mixture was stirred for $15 \mathrm{~min}$ at -78 ${ }^{\circ} \mathrm{C}$, benzyl bromide added $(0.12 \mathrm{~mL}, 1.00 \mathrm{mmol})$ and stirred for a further $5 \mathrm{~min}$. The reaction mixture was warmed to $\mathrm{rt}$ and the solvent removed under reduced pressure. Diethyl ether (30 $\mathrm{mL})$ was added to the residue, washed with $\mathrm{HCl}(2 \mathrm{M}, 3 \times 10 \mathrm{~mL})$, dried over sodium sulphate and concentrated to dryness. Purification by silica gel chromatography eluting with 92:8 cyclohexane:diethyl ether gave 1,2-diphenylethane $\mathbf{3 a}\left(\mathrm{R}_{f}=0.80,135 \mathrm{mg}\right)$ contaminated by benzyl bromide.

1,2-Diphenylethane (3a). ${ }^{22}$ A solution of toluene $1 \mathbf{a}(46 \mathrm{mg}, 0.50 \mathrm{mmol})$ in THF (15 mL) at -78 ${ }^{\circ} \mathrm{C}$ was treated dropwise with $\mathrm{BuLi}(2.37 \mathrm{M}, 0.25 \mathrm{~mL}, 0.60 \mathrm{mmol})$ and stirred for $5 \mathrm{~min} . \mathrm{KO} t \mathrm{Bu}$ (1.0 $\mathrm{M}$ in THF, $0.60 \mathrm{~mL}, 0.60 \mathrm{mmol}$ ) was added dropwise followed by 2,2,6,6tetramethylpiperidine $(84 \mu \mathrm{L}, 0.50 \mathrm{mmol})$. The reaction mixture was stirred for $15 \mathrm{~min}$ at -78 ${ }^{\circ} \mathrm{C}$, 1,2-dibromoethane added $(0.13 \mathrm{~mL}, 1.50 \mathrm{mmol})$ and stirred for a further $5 \mathrm{~min}$. The reaction mixture was warmed to $\mathrm{rt}$ and the solvent removed under reduced pressure. Diethyl ether (30 $\mathrm{mL}$ ) was added to the residue, washed with $\mathrm{HCl}(2 \mathrm{M}, 3 \times 10 \mathrm{~mL})$, dried over sodium sulphate and concentrated to dryness. Purification by silica gel chromatography eluting with 92:8 cyclohexane:diethyl ether gave 1,2-diphenylethane 3a as a colorless solid $\left(\mathrm{R}_{f}=0.80,32 \mathrm{mg}\right.$, 71\%). mp. 50-51 ${ }^{\circ} \mathrm{C}$, lit. mp. 51-53 ${ }^{\circ} \mathrm{C} .{ }^{22 \mathrm{~b}}{ }^{1} \mathrm{H}$ NMR $\left(500 \mathrm{MHz}, \mathrm{CDCl}_{3}\right): \delta$ 7.29-7.23 (m, 4H), 
7.20-7.15 (m, 6H), $2.91(\mathrm{~s}, 4 \mathrm{H}) .{ }^{13} \mathrm{C}$ NMR $\left(125 \mathrm{MHz}, \mathrm{CDCl}_{3}\right): \delta 141.8,128.5,128.3,125.9$, 37.9. HRMS $[\mathrm{M}]^{+}: 182.1092, \mathrm{C}_{14} \mathrm{H}_{14}$ requires 182.1096 .

1,2-Bis(2-fluorophenyl)ethane (3b). ${ }^{23}$ A solution of 2-fluorotoluene $\mathbf{1 b}(165 \mathrm{mg}, 1.50 \mathrm{mmol})$ in THF (15 mL) at $-78{ }^{\circ} \mathrm{C}$ was treated dropwise with BuLi (2.37 M, $\left.0.76 \mathrm{~mL}, 1.80 \mathrm{mmol}\right)$ and stirred for $5 \mathrm{~min} . \mathrm{KO} t \mathrm{Bu}(1.0 \mathrm{M}$ in THF, $1.80 \mathrm{~mL}, 1.80 \mathrm{mmol})$ was added dropwise followed by 2,2,6,6-tetramethylpiperidine $(0.25 \mathrm{~mL}, 1.50 \mathrm{mmol})$. The reaction mixture was stirred for $15 \mathrm{~min}$ at $-78{ }^{\circ} \mathrm{C}, 1,2$-dibromoethane $(0.37 \mathrm{~mL}, 4.50 \mathrm{mmol})$ added and stirred for a further $5 \mathrm{~min}$. The reaction mixture was warmed to $\mathrm{rt}$ and the solvent removed under reduced pressure. Diethyl ether $(30 \mathrm{~mL})$ was added to the residue, washed with $\mathrm{HCl}(2 \mathrm{M}, 3 \times 10 \mathrm{~mL})$, dried over sodium sulphate and concentrated to dryness. Purification by silica gel chromatography eluting with 90:10 cyclohexane:diethyl ether gave $\mathbf{3 b}$ as a colorless solid $\left(\mathrm{R}_{f}=0.80,128 \mathrm{mg}, 78 \%, \mathrm{mp}\right.$. 40-41 ${ }^{\circ} \mathrm{C}$ lit. mp. 40-41 ${ }^{\circ} \mathrm{C}$ ). ${ }^{23 \mathrm{~b}} \quad{ }^{1} \mathrm{H}$ NMR $\left(500 \mathrm{MHz}, \mathrm{CDCl}_{3}\right): \delta$ 7.21-7.09 (m, 4H), 7.04-6.98 (m, 4H), $2.94(\mathrm{~s}, 4 \mathrm{H}) .{ }^{13} \mathrm{C} \mathrm{NMR}\left(125 \mathrm{MHz}, \mathrm{CDCl}_{3}\right): \delta 161.2(\mathrm{~d}, J=244.9 \mathrm{~Hz}), 130.7(\mathrm{~d}, J=5.0 \mathrm{~Hz})$, $128.3(\mathrm{dd}, J=18.8,15.0 \mathrm{~Hz}), 127.7(\mathrm{~d}, J=8.1 \mathrm{~Hz}), 123.8(\mathrm{~d}, J=3.6 \mathrm{~Hz}), 115.2(\mathrm{~d}, J=22.1 \mathrm{~Hz})$, 29.7-29.6 (m). HRMS [M] $]^{+}: 218.0912, \mathrm{C}_{14} \mathrm{H}_{12} \mathrm{~F}_{2}$ requires 218.0907.

2,2'-(Ethane-1,2-diyl)bis(N,N-dimethylaniline) (3c). A solution of $N, N$-dimethyl-o-toluidine 1c (203 mg, $1.50 \mathrm{mmol})$ in THF $(15 \mathrm{~mL})$ at $-78{ }^{\circ} \mathrm{C}$ was treated dropwise with $\mathrm{BuLi}(2.37 \mathrm{M}, 0.76$ $\mathrm{mL}, 1.8 \mathrm{mmol})$ and stirred for $5 \mathrm{~min} . \mathrm{KO} t \mathrm{Bu}(1.0 \mathrm{M}$ in THF, $1.80 \mathrm{~mL}, 1.80 \mathrm{mmol})$ was added dropwise followed by 2,2,6,6-tetramethylpiperidine $(0.25 \mathrm{~mL}, 1.50 \mathrm{mmol})$. The reaction mixture was stirred for $15 \mathrm{~min}$ at $-78{ }^{\circ} \mathrm{C}, 1,2$-dibromoethane $(0.37 \mathrm{~mL}, 4.50 \mathrm{mmol})$ added and stirred for a further $5 \mathrm{~min}$. The reaction mixture was warmed to rt and the solvent removed under reduced pressure. Diethyl ether $(30 \mathrm{~mL})$ was added to the residue, washed with water $(3 \times 10 \mathrm{~mL})$, dried over sodium sulphate and concentrated to dryness. Purification by silica gel chromatography eluting with 80:20 cyclohexane:diethyl ether $\left(0.5 \% \mathrm{Et}_{3} \mathrm{~N}\right)$ gave $3 \mathbf{c}$ as a colorless solid $\left(\mathrm{R}_{f}=0.60\right.$, $116 \mathrm{mg}, 58 \%$, mp. $\left.53-54{ }^{\circ} \mathrm{C}\right) .{ }^{1} \mathrm{H}$ NMR $\left(500 \mathrm{MHz}, \mathrm{CDCl}_{3}\right): \delta 7.28(\mathrm{~d}, J=7.5 \mathrm{~Hz}, 2 \mathrm{H}), 7.17(\mathrm{t}, J$ $=7.5 \mathrm{~Hz}, 2 \mathrm{H}), 7.11(\mathrm{~d}, J=7.9 \mathrm{~Hz}, 2 \mathrm{H}), 7.02(\mathrm{t}, J=7.4 \mathrm{~Hz}, 2 \mathrm{H}), 3.03(\mathrm{~s}, 4 \mathrm{H}), 2.68(\mathrm{~s}, 12 \mathrm{H}) .{ }^{13} \mathrm{C}$ NMR $\left(125 \mathrm{MHz}, \mathrm{CDCl}_{3}\right): \delta 152.9,137.4,129.8,126.6,123.4,119.6,45.2,31.9$. HRMS $[\mathrm{M}]^{+}$: 268.1937, $\mathrm{C}_{18} \mathrm{H}_{24} \mathrm{~N}_{2}$ requires 268.1939. Analysis calcd for $\mathrm{C}_{18} \mathrm{H}_{24} \mathrm{~N}_{2}: \mathrm{C}, 80.55 ; \mathrm{H}, 9.01 ; \mathrm{N}, 10.44$. Found: C, 80.49; H, 8.86; N, 10.17.

2,2'-(Ethane-1,2-diyl)dibenzoic acid (3d). ${ }^{24}$ A solution of $o$-toluic acid $\mathbf{1 d}(272 \mathrm{mg}, 2.00 \mathrm{mmol})$ in THF (18 mL) at $-78{ }^{\circ} \mathrm{C}$ was treated dropwise with BuLi $(2.30 \mathrm{M}, 1.74 \mathrm{~mL}, 4.00 \mathrm{mmol})$ and 
stirred for $5 \mathrm{~min}$. KOtBu (1.0 M in THF, $4.00 \mathrm{~mL}, 4.00 \mathrm{mmol})$ was added dropwise followed by 2,2,6,6-tetramethylpiperidine $(0.34 \mathrm{~mL}, 2.00 \mathrm{mmol})$. The reaction mixture was stirred for $15 \mathrm{~min}$ at $-78{ }^{\circ} \mathrm{C}, 1,2$-dibromoethane $(0.52 \mathrm{~mL}, 6.00 \mathrm{mmol})$ added and stirred for a further $5 \mathrm{~min}$. The reaction mixture was warmed to $\mathrm{rt}$ and the solvent removed under reduced pressure. Diethyl ether $(30 \mathrm{~mL})$ was added to the residue, washed with $\mathrm{HCl}(2 \mathrm{M}, 3 \times 10 \mathrm{~mL})$, dried over sodium sulphate and concentrated to dryness. Trituration from diethyl ether with cooling gave $\mathbf{3 d}$ as a pale yellow solid (144 mg, 53\%, mp. 228-229 ${ }^{\circ} \mathrm{C}$, lit. mp. 229-231 $\left.{ }^{\circ} \mathrm{C}\right) .{ }^{24 \mathrm{~b}}{ }^{1} \mathrm{H} \mathrm{NMR}(500 \mathrm{MHz}$, DMSO-d $\left.)_{6}\right): \delta 12.86(\mathrm{bs}, 2 \mathrm{H}), 7.82(\mathrm{~d}, J=7.8 \mathrm{~Hz}, 2 \mathrm{H}), 7.45(\mathrm{td}, J=7.5,1.1 \mathrm{~Hz}, 2 \mathrm{H}), 7.31-7.24$ (m, 4H), 3.19 (s, 4H). ${ }^{13} \mathrm{C}$ NMR (125 MHz, DMSO-d6): $\delta 169.2,143.2,132.1,131.0,130.9$, 130.7, 126.5, 36.0. HRMS [M+Na] $]^{+}$293.0796, $\mathrm{C}_{16} \mathrm{H}_{14} \mathrm{O}_{4} \mathrm{Na}$ requires 293.0790.

1,2-Bis(2-methoxyphenyl)ethane (3e) ${ }^{25}$ A solution of 2-methylanisole 1e (122 mg, $\left.1.00 \mathrm{mmol}\right)$ in THF $(15 \mathrm{~mL})$ at $-78{ }^{\circ} \mathrm{C}$ was treated dropwise with BuLi $(2.50 \mathrm{M}, 0.48 \mathrm{~mL}, 1.20 \mathrm{mmol})$ and stirred for $5 \mathrm{~min}$. $\mathrm{KO} t \mathrm{Bu}(1.0 \mathrm{M}$ in $\mathrm{THF}, 1.20 \mathrm{~mL}, 1.20 \mathrm{mmol})$ was added dropwise followed by 2,2,6,6-tetramethylpiperidine $(0.17 \mathrm{~mL}, 1.00 \mathrm{mmol})$. The reaction mixture was stirred for $15 \mathrm{~min}$ at $-78{ }^{\circ} \mathrm{C}, 1,2$-dibromoethane $(0.26 \mathrm{~mL}, 3.00 \mathrm{mmol})$ added and stirred for a further $5 \mathrm{~min}$. The reaction mixture was warmed to $\mathrm{rt}$ and the solvent removed under reduced pressure. Diethyl ether $(30 \mathrm{~mL})$ was added to the residue, washed with $\mathrm{HCl}(2 \mathrm{M}, 3 \times 10 \mathrm{~mL})$, dried over sodium sulphate and concentrated to dryness. Purification by silica gel chromatography eluting with 98:2 cyclohexane:diethyl ether gave $\mathbf{3 e}$ as a colorless solid $\left(\mathrm{R}_{f}=0.70,76 \mathrm{mg}, 63 \%\right.$, mp. $78-79{ }^{\circ} \mathrm{C}$, lit. mp. 81-82 $\left.{ }^{\circ} \mathrm{C}\right) .{ }^{25}{ }^{1} \mathrm{H}$ NMR $\left(500 \mathrm{MHz}, \mathrm{CDCl}_{3}\right): \delta 7.16(\mathrm{t}, J=7.8 \mathrm{~Hz}, 2 \mathrm{H}), 7.11(\mathrm{~d}, J=7.3 \mathrm{~Hz}$, 2H), 6.90-6.78 (m, 4H), $3.80(\mathrm{~s}, 6 \mathrm{H}), 2.89(\mathrm{~s}, 4 \mathrm{H}) .{ }^{13} \mathrm{C} \mathrm{NMR}\left(125 \mathrm{MHz}, \mathrm{CDCl}_{3}\right): \delta$ 156.5, 129.8, 128.7, 125.9, 119.3, 109.2, 54.3, 29.4. HRMS [M] ${ }^{+}:$242.1298, $\mathrm{C}_{16} \mathrm{H}_{18} \mathrm{O}_{2}$ requires 242.1307.

1,2-Bis(3-methoxyphenyl)ethane (3f). ${ }^{26}$ A solution of 3-methylanisole $\mathbf{1 f}(122 \mathrm{mg}, 1.00 \mathrm{mmol})$ in THF (15 mL) at $-78{ }^{\circ} \mathrm{C}$ was treated dropwise with BuLi $(2.50 \mathrm{M}, 0.48 \mathrm{~mL}, 1.20 \mathrm{mmol})$ and stirred for $5 \mathrm{~min}$. KOtBu (1.0 M in THF, $1.20 \mathrm{~mL}, 1.20 \mathrm{mmol})$ was added dropwise followed by 2,2,6,6-tetramethylpiperidine $(0.17 \mathrm{~mL}, 1.00 \mathrm{mmol})$. The reaction mixture was stirred for $15 \mathrm{~min}$ at $-78{ }^{\circ} \mathrm{C}, 1,2$-dibromoethane $(0.26 \mathrm{~mL}, 3.00 \mathrm{mmol})$ added and stirred for a further $5 \mathrm{~min}$. The reaction mixture was warmed to $\mathrm{rt}$ and the solvent removed under reduced pressure. Diethyl ether $(30 \mathrm{~mL})$ was added to the residue, washed with $\mathrm{HCl}(2 \mathrm{M}, 3 \times 10 \mathrm{~mL})$, dried over sodium sulphate and concentrated to dryness. Purification by silica gel chromatography eluting with 96:4 cyclohexane:diethyl ether gave $\mathbf{3 f}$ as a colorless oil $\left(\mathrm{R}_{f}=0.60,82 \mathrm{mg}, 68 \%\right) .{ }^{1} \mathrm{H}$ NMR $(500$ 
$\left.\mathrm{MHz}, \mathrm{CDCl}_{3}\right): \delta 7.19(\mathrm{t}, J=7.7 \mathrm{~Hz}, 2 \mathrm{H}), 6.79-6.71(\mathrm{~m}, 6 \mathrm{H}), 3.77(\mathrm{~s}, 6 \mathrm{H}), 2.89(\mathrm{~s}, 4 \mathrm{H}) .{ }^{13} \mathrm{C} \mathrm{NMR}$ $\left(125 \mathrm{MHz}, \mathrm{CDCl}_{3}\right): \delta 159.6,143.4,129.3,120.9,114.2,111.3,55.1,37.8$. HRMS $[\mathrm{M}+\mathrm{H}]^{+}$: 243.1377, $\mathrm{C}_{16} \mathrm{H}_{19} \mathrm{O}_{2}$ requires 243.1385.

1,2-Bis(3-(methoxymethoxy)phenyl)ethane (3g). A solution of 1-methoxymethoxy-3methylbenzene $1 \mathrm{~g}$ (250 $\mathrm{mg}, 1.64 \mathrm{mmol})$ in THF $(20 \mathrm{~mL})$ at $-78{ }^{\circ} \mathrm{C}$ was treated dropwise with BuLi (2.40 M, $0.82 \mathrm{~mL}, 1.97 \mathrm{mmol})$ and stirred for $5 \mathrm{~min}$. KOtBu (1.0 M in THF, $1.97 \mathrm{~mL}, 1.97$ mmol) was added dropwise followed by 2,2,6,6-tetramethylpiperidine $(0.28 \mathrm{~mL}, 1.64 \mathrm{mmol})$. The reaction mixture was stirred for $15 \mathrm{~min}$ at $-78{ }^{\circ} \mathrm{C}, 1,2$-dibromoethane $(0.42 \mathrm{~mL}, 4.92 \mathrm{mmol})$ added and stirred for a further $5 \mathrm{~min}$. The reaction mixture was warmed to $\mathrm{rt}$ and the solvent removed under reduced pressure. The residue was dissolved in diethyl ether $(30 \mathrm{~mL})$, washed with $2 \mathrm{M} \mathrm{HCl}(3 \times 10 \mathrm{~mL})$, dried over sodium sulfate and concentrated to dryness. Purification by alumina gel chromatography eluting with 99:1 cyclohexane:ethyl acetate gave $\mathbf{3 g}$ as a colorless oil $\left(\mathrm{R}_{f}=0.60,115 \mathrm{mg}, 46 \%\right) .{ }^{1} \mathrm{H}$ NMR $\left(400 \mathrm{MHz}, \mathrm{CDCl}_{3}\right): \delta$ 7.22-7.18 (m, 2H), 6.89$6.84(\mathrm{~m}, 6 \mathrm{H}), 5.16(\mathrm{~s}, 4 \mathrm{H}), 3.48(\mathrm{~s}, 6 \mathrm{H}), 2.90(\mathrm{~s}, 4 \mathrm{H}) .{ }^{13} \mathrm{C} \mathrm{NMR}\left(100 \mathrm{MHz}, \mathrm{CDCl}_{3}\right): \delta 157.34$, 143.39, 129.30, 122.07, 116.44, 113.78, 94.50, 55.95, 37.73. HRMS [M] $]^{+}: 302.1519, \mathrm{C}_{18} \mathrm{H}_{22} \mathrm{O}_{4}$ requires 302.1518 .

4,4'-(Ethane-1,2-diyl)bis(N,N-diisopropylbenzamide) (3h). A solution of $N, N$-diisopropyl-4methylbenzamide $\mathbf{1 h}(219 \mathrm{mg}, 1.00 \mathrm{mmol})$ in THF $(15 \mathrm{~mL})$ at $-78{ }^{\circ} \mathrm{C}$ was treated dropwise with $\mathrm{BuLi}(2.50 \mathrm{M}, 0.48 \mathrm{~mL}, 1.20 \mathrm{mmol})$ and stirred for $5 \mathrm{~min}$. $\mathrm{KO} t \mathrm{Bu}(1.0 \mathrm{M}$ in THF, $1.20 \mathrm{~mL}, 1.20$ $\mathrm{mmol}$ ) was added dropwise followed by 2,2,6,6-tetramethylpiperidine $(0.17 \mathrm{~mL}, 1.00 \mathrm{mmol})$. The reaction mixture was stirred for $15 \mathrm{~min}$ at $-78{ }^{\circ} \mathrm{C}, 1,2$-dibromoethane $(0.26 \mathrm{~mL}, 3.00 \mathrm{mmol})$ added and stirred for a further $5 \mathrm{~min}$. The reaction mixture was warmed to $\mathrm{rt}$ and the solvent removed under reduced pressure. Diethyl ether $(30 \mathrm{~mL})$ was added to the residue, washed with 2 $\mathrm{M} \mathrm{HCl}(3 \times 10 \mathrm{~mL})$, dried over sodium sulfate and concentrated to dryness. Purification by silica gel chromatography eluting with 15:85 cyclohexane:diethyl ether gave $\mathbf{3 h}$ as a colorless solid $\left(\mathrm{R}_{f}\right.$ $=0.60,96 \mathrm{mg}, 88 \%$, mp. $\left.144-145{ }^{\circ} \mathrm{C}\right) .{ }^{1} \mathrm{H} \mathrm{NMR}\left(500 \mathrm{MHz}, \mathrm{CDCl}_{3}\right): \delta 7.23(\mathrm{~d}, 4 \mathrm{H}, J=7.9 \mathrm{~Hz})$, 7.17 (d, 4H, J=7.9 Hz), 3.69 (bs, 4H), 2.93 (s, 4H), 1.33 (bs, 24H). ${ }^{13} \mathrm{C}$ NMR (125 MHz, CDCl $)$ : $\delta 171.1,142.1,136.7,128.4,125.8,37.4,20.8$. (Note: $i \operatorname{Pr}$ tertiary $\mathrm{C}$ not observed). HRMS $[\mathrm{M}+\mathrm{H}]^{+}:$437.3188, $\mathrm{C}_{28} \mathrm{H}_{41} \mathrm{~N}_{2} \mathrm{O}_{2}$ requires 437.3168. Analysis calcd for $\mathrm{C}_{28} \mathrm{H}_{40} \mathrm{~N}_{2} \mathrm{O}_{2}$ : C, $77.02 ; \mathrm{H}$, 9.23; N, 6.42. Found: C, 76.73; H, 9.34; N, 6.30 . 
1,2-Bis(3,5-dimethoxyphenyl)ethane (3i). ${ }^{27}$ A solution of 2,2,6,6-tetramethylpiperidine $(0.22 \mathrm{~mL}$, $1.31 \mathrm{mmol})$ in THF $(10 \mathrm{~mL})$ at $-78^{\circ} \mathrm{C}$ was treated dropwise with BuLi $(2.35 \mathrm{M}, 0.67 \mathrm{~mL}, 1.57$ $\mathrm{mmol})$ and stirred for $5 \mathrm{~min}$. $\mathrm{KOtBu}(1.0 \mathrm{M}$ in THF, $1.57 \mathrm{~mL}, 1.57 \mathrm{mmol})$ was added dropwise and stirred for $5 \mathrm{~min}$. A solution of 3,5-dimethoxytoluene 1i (200 mg, $1.31 \mathrm{mmol}$ ) in THF (5 $\mathrm{mL}$ ) at $-78{ }^{\circ} \mathrm{C}$ was added dropwise to the reaction mixture and stirred for $15 \mathrm{~min}$ at $-78{ }^{\circ} \mathrm{C}$. Then 1,2-dibromoethane $(0.34 \mathrm{~mL}, 3.93 \mathrm{mmol})$ was added and the mixture was stirred for a further $5 \mathrm{~min}$. The reaction mixture was warmed to $\mathrm{rt}$ and the solvent removed under reduced pressure. The residue was dissolved in diethyl ether $(30 \mathrm{~mL})$, washed with $2 \mathrm{M} \mathrm{HCl}(3 \times 10 \mathrm{~mL})$, dried over sodium sulfate and concentrated to dryness to give $\mathbf{3 i}$ as a colorless solid (160 mg, 80\%, mp. 96-97 ${ }^{\circ} \mathrm{C}$, lit. mp. 99-100 ${ }^{\circ} \mathrm{C}$ ). ${ }^{27 \mathrm{~b}}{ }^{1} \mathrm{H}$ NMR (400 MHz, $\left.\mathrm{CDCl}_{3}\right): \delta$ 6.36-6.35 (m, 4H), 6.33-6.32 (m, 2H), $3.77(\mathrm{~s}, 12 \mathrm{H}), 2.85(\mathrm{~s}, 4 \mathrm{H}) .{ }^{13} \mathrm{C} \mathrm{NMR}\left(100 \mathrm{MHz}, \mathrm{CDCl}_{3}\right): \delta$ 160.7, 144.1, 106.5, 98.0, 55.3, 38.0. HRMS $[\mathrm{M}+\mathrm{H}]^{+}: 303.1600, \mathrm{C}_{18} \mathrm{H}_{23} \mathrm{O}_{4}$ requires 303.1596.

1,2-Bis(3-methoxy-4-methylphenyl)ethane (3j). A solution of 2,5-dimethylanisole $\mathbf{1 j}$ (209 mg, $1.50 \mathrm{mmol})$ in THF $(15 \mathrm{~mL})$ at $-78{ }^{\circ} \mathrm{C}$ was treated dropwise with BuLi $(2.50 \mathrm{M}$ in hexanes, 0.72 $\mathrm{mL}, 1.80 \mathrm{mmol})$ and stirred for $5 \mathrm{~min}$. $\mathrm{KO} t \mathrm{Bu}(1.0 \mathrm{M}$ in THF, $1.80 \mathrm{~mL}, 1.80 \mathrm{mmol})$ was added dropwise followed by 2,2,6,6-tetramethylpiperidine $(0.26 \mathrm{~mL}, 1.50 \mathrm{mmol})$. The reaction mixture was stirred for $15 \mathrm{~min}$ at $-78{ }^{\circ} \mathrm{C}, 1,2$-dibromoethane $(0.37 \mathrm{~mL}, 4.50 \mathrm{mmol})$ added and stirred for a further $5 \mathrm{~min}$. The reaction mixture was warmed to $\mathrm{rt}$ and the solvent removed under reduced pressure. The residue was dissolved in diethyl ether $(30 \mathrm{~mL})$, washed with $2 \mathrm{M} \mathrm{HCl}(3 \times 10 \mathrm{~mL})$, dried over sodium sulfate and concentrated to dryness. Purification by silica gel chromatography eluting with 98:2 cyclohexane:EtOAc gave $\mathbf{3 j}$ as a colorless solid $\left(\mathrm{R}_{f}=0.50,178 \mathrm{mg}, 88 \%\right.$, mp. 70-71 $\left.{ }^{\circ} \mathrm{C}\right) .{ }^{1} \mathrm{H}$ NMR $\left(500 \mathrm{MHz}, \mathrm{CDCl}_{3}\right): \delta 7.03(\mathrm{~d}, J=7.5 \mathrm{~Hz}, 2 \mathrm{H}), 6.71(\mathrm{~d}, J=7.5 \mathrm{~Hz}, 2 \mathrm{H})$, $6.62(\mathrm{~s}, 2 \mathrm{H}), 3.78(\mathrm{~s}, 6 \mathrm{H}), 2.88(\mathrm{~s}, 4 \mathrm{H}), 2.18(\mathrm{~s}, 6 \mathrm{H}) .{ }^{13} \mathrm{C} \mathrm{NMR}\left(125 \mathrm{MHz}, \mathrm{CDCl}_{3}\right): \delta$ 157.6, 140.7, 130.4, 124.0, 120.1, 110.4, 55.2, 38.1, 15.8. HRMS $[\mathrm{M}+\mathrm{H}]^{+}: 271.1708, \mathrm{C}_{18} \mathrm{H}_{23} \mathrm{O}_{2}$ requires 271.1698. Analysis calcd for $\mathrm{C}_{18} \mathrm{H}_{22} \mathrm{O}_{2}: \mathrm{C}, 79.96 ; \mathrm{H}, 8.20$. Found: $\mathrm{C}, 79.68 ; \mathrm{H}, 8.27$.

1,2-Bis(3,4,5-trimethoxyphenyl)ethane $\quad(\mathbf{3 k}) \quad$ (brittonin $\quad$ A). ${ }^{28} \quad \mathrm{~A}$ solution of $3,4,5-$ trimethoxytoluene $1 \mathbf{k}(182 \mathrm{mg}, 1.00 \mathrm{mmol})$ in $\mathrm{THF}(15 \mathrm{~mL})$ at $-78{ }^{\circ} \mathrm{C}$ was treated dropwise with $\operatorname{BuLi}(2.50 \mathrm{M}$ in hexanes, $0.48 \mathrm{~mL}, 1.20 \mathrm{mmol})$ and stirred for $5 \mathrm{~min}$. $\mathrm{KO} t \mathrm{Bu}(1.0 \mathrm{M}$ in THF, $1.20 \mathrm{~mL}, 1.20 \mathrm{mmol}$ ) was added dropwise followed by 2,2,6,6-tetramethylpiperidine $(0.17 \mathrm{~mL}$, $1.00 \mathrm{mmol})$. The reaction mixture was stirred for $15 \mathrm{~min}$ at $-78{ }^{\circ} \mathrm{C}, 1,2$-dibromoethane $(0.26$ $\mathrm{mL}, 3.00 \mathrm{mmol}$ ) added and stirred for a further $5 \mathrm{~min}$. The reaction mixture was warmed to $\mathrm{rt}$ 
and the solvent removed under reduced pressure. The residue was dissolved in diethyl ether (30 $\mathrm{mL})$, washed with $2 \mathrm{M} \mathrm{HCl}(3 \times 10 \mathrm{~mL})$, dried over sodium sulfate and concentrated to dryness. Triturating from diethyl ether with cooling gave 3k as a colorless solid (125 mg, 69\%, mp. 138$139{ }^{\circ} \mathrm{C}$, lit. mp. $\left.138-139{ }^{\circ} \mathrm{C}\right) .{ }^{28 \mathrm{~b}}{ }^{1} \mathrm{H}$ NMR $\left(500 \mathrm{MHz}, \mathrm{CDCl}_{3}\right): 6.36$ (s, 4H), 3.82 (s, 18H), 2.85 (s, 4H). ${ }^{13} \mathrm{C}$ NMR $\left(125 \mathrm{MHz}, \mathrm{CDCl}_{3}\right): \delta 153.0,137.3,136.3,105.6,60.8,56.1,38.4$. HRMS $[\mathrm{M}+\mathrm{Na}]^{+}: 385.1637, \mathrm{C}_{20} \mathrm{H}_{26} \mathrm{O}_{6} \mathrm{Na}$ requires 385.1627.

General procedure for the optimization of heterocoupling reaction. A solution of toluene 1a and 3-methylanisole $\mathbf{1 f}$ in THF $(20 \mathrm{~mL})$ at $-78{ }^{\circ} \mathrm{C}$ was treated dropwise with BuLi $(2.37 \mathrm{M})$ and stirred for $5 \mathrm{~min}$. $\mathrm{KO} t \mathrm{Bu}(1.0 \mathrm{M}$ in $\mathrm{THF})$ was added dropwise followed by 2,2,6,6tetramethylpiperidine. The reaction mixture was stirred for $15 \mathrm{~min}$ at $-78^{\circ} \mathrm{C}, 1,2$-dibromoethane $(0.22 \mathrm{~mL}, 5.00$ equiv.) added and stirred for a further $5 \mathrm{~min}$. The reaction mixture was warmed to room temperature and the solvent removed under reduced pressure. Diethyl ether $(30 \mathrm{~mL})$ was added to the residue, washed with $\mathrm{HCl}(2 \mathrm{M}, 3 \times 10 \mathrm{~mL})$, dried over sodium sulphate and concentrated to dryness. Purification by silica gel chromatography eluting with 96:4 cyclohexane:diethyl ether gave 1-methoxy-3-phenethylbenzene $4 \mathrm{a}$ as a colorless oil $\left(\mathrm{R}_{f}=0.60\right)$. Tabulated results:

\begin{tabular}{ccccccc}
\hline entry & $\begin{array}{c}\mathbf{1 a} \\
(\mathrm{mg}, \mathrm{mmol})\end{array}$ & $\begin{array}{c}\mathbf{1 f} \\
(\mathrm{mg}, \mathrm{mmol})\end{array}$ & $\begin{array}{c}\text { Li:K:TMP } \\
(\mathrm{eq} .)\end{array}$ & $\begin{array}{c}\mathbf{4 a} \\
(\mathrm{mg}, \mathrm{mmol}, \\
\text { yield } \%)\end{array}$ & $\begin{array}{c}\mathbf{3 a} \\
(\mathrm{mg}, \mathrm{mmol})\end{array}$ & $\begin{array}{c}\mathbf{3 f} \\
(\mathrm{mg}, \mathrm{mmol})\end{array}$ \\
\hline 1 & $46,0.50$ & $61,0.50$ & $2.2: 2.2: 2$ & $26,0.121,24 \%$ & $21,0.115$ & $23,0.094$ \\
2 & $92,1.00$ & $61,0.50$ & $3.3: 3.3: 3$ & $43,0.202,41 \%$ & $72,0.395$ & $23,0.095$ \\
3 & $46,0.50$ & $122,1.00$ & $3.3: 3.3: 3$ & $41,0.195,39 \%$ & $25,0.139$ & $60,0.248$ \\
\hline
\end{tabular}

1-Methoxy-3-phenethylbenzene (4a). ${ }^{11}$ A solution of 3-methylanisole $\mathbf{1 f}(61 \mathrm{mg}, 0.50 \mathrm{mmol})$ and toluene 1a (92 $\mathrm{mg}, 1.00 \mathrm{mmol})$ in THF $(20 \mathrm{~mL})$ at $-78{ }^{\circ} \mathrm{C}$ was treated dropwise with BuLi (2.37 M, $0.69 \mathrm{~mL}, 1.65 \mathrm{mmol}$ ) and stirred for $5 \mathrm{~min} . \mathrm{KOtBu}(1.0 \mathrm{M}$ in THF, $1.65 \mathrm{~mL}, 1.65 \mathrm{mmol}$ ) was added dropwise followed by 2,2,6,6-tetramethylpiperidine $(0.25 \mathrm{~mL}, 1.50 \mathrm{mmol})$. The reaction mixture was stirred for $15 \mathrm{~min}$ at $-78{ }^{\circ} \mathrm{C}, 1,2$-dibromoethane $(0.22 \mathrm{~mL}, 2.50 \mathrm{mmol})$ added and stirred for a further $5 \mathrm{~min}$. The reaction mixture was warmed to $\mathrm{rt}$ and the solvent removed under reduced pressure. Diethyl ether $(30 \mathrm{~mL})$ was added to the residue, washed with $\mathrm{HCl}$ ( $2 \mathrm{M}, 3 \times 10 \mathrm{~mL}$ ), dried over sodium sulphate and concentrated to dryness. Purification by 
silica gel chromatography eluting with 96:4 cyclohexane:diethyl ether gave 1-methoxy-3phenethylbenzene $4 \mathbf{a}$ as a colorless oil $\left(\mathrm{R}_{f}=0.60,43 \mathrm{mg}, 41 \%\right)$. ${ }^{1} \mathrm{H}$ NMR (500 $\left.\mathrm{MHz}, \mathrm{CDCl}_{3}\right): \delta$ 7.29-7.25 (m, 2H), 7.21-7.16 (m, 4H), 6.80-6.70 (m, 3H), 3.77 (s, 3H), 2.95-2.86 (m, 4H). ${ }^{13} \mathrm{C}$ NMR (125 MHz, $\left.\mathrm{CDCl}_{3}\right): \delta 159.6,143.4,141.7,129.3,128.4,128.3,125.9,120.9,114.2,111.3$, 55.1, 37.9, 37.8. HRMS [M] $]^{+}$212.1209, $\mathrm{C}_{15} \mathrm{H}_{16} \mathrm{O}$ requires 212.1201.

1-(Methoxymethoxy)-3-phenethylbenzene (4b). ${ }^{29}$ A solution of 1-(methoxymethoxy)-3methylbenzene $1 \mathbf{g}(76 \mathrm{mg}, 0.50 \mathrm{mmol})$ and toluene $\mathbf{1 a}(92 \mathrm{mg}, 1.00 \mathrm{mmol})$ in THF (20 mL) at $-78{ }^{\circ} \mathrm{C}$ was treated dropwise with BuLi $(2.50 \mathrm{M}, 0.66 \mathrm{~mL}, 1.65 \mathrm{mmol})$ and stirred for $5 \mathrm{~min}$. $\mathrm{KO} t \mathrm{Bu}(1.0 \mathrm{M}$ in $\mathrm{THF}, 1.65 \mathrm{~mL}, 1.65 \mathrm{mmol})$ was added dropwise followed by 2,2,6,6tetramethylpiperidine $(0.25 \mathrm{~mL}, 1.50 \mathrm{mmol})$. The reaction mixture was stirred for $15 \mathrm{~min}$ at -78 ${ }^{\circ} \mathrm{C}, 1,2$-dibromoethane $(0.22 \mathrm{~mL}, 2.50 \mathrm{mmol})$ added and stirred for a further $5 \mathrm{~min}$. The reaction mixture was warmed to $\mathrm{rt}$ and the solvent removed under reduced pressure. Diethyl ether (30 $\mathrm{mL}$ ) was added to the residue, washed with $\mathrm{HCl}(2 \mathrm{M}, 3 \times 10 \mathrm{~mL})$, dried over sodium sulphate and concentrated to dryness. Purification by silica gel chromatography eluting with 94:6 cyclohexane:diethyl ether $\left(0.25 \% \mathrm{Et}_{3} \mathrm{~N}\right)$ gave $\mathbf{4 b}$ as a colorless oil $\left(\mathrm{R}_{f}=0.60,53 \mathrm{mg}, 43 \%\right) .{ }^{1} \mathrm{H}$ NMR (500 MHz, $\left.\mathrm{CDCl}_{3}\right): \delta$ 7.30-7.26 (m, 2H), 7.22-7.17 (m, 4H), 6.90-6.82 (m, 3H), $5.15(\mathrm{~s}$, 2H), $3.48(\mathrm{~s}, 3 \mathrm{H}), 2.95-2.87(\mathrm{~m}, 4 \mathrm{H}) .{ }^{13} \mathrm{C} \mathrm{NMR}\left(125 \mathrm{MHz}, \mathrm{CDCl}_{3}\right): \delta 157.3,143.5,141.7,129.3$, $128.4,128.3,125.9,122.1,116.4,113.7,94.5,55.9,37.9,37.8$. HRMS $[\mathrm{M}+\mathrm{Na}]^{+}:$265.1204, $\mathrm{C}_{16} \mathrm{H}_{18} \mathrm{O}_{2} \mathrm{Na}$ requires 265.1204 .

3-Phenethylphenol (4c). ${ }^{13}$ A solution of 1-(methoxymethoxy)-3-phenethylbenzene $\mathbf{4 b}$ (52 mg, $0.22 \mathrm{mmol})$ in methanol $(15 \mathrm{~mL})$ was treated dropwise with conc. $\mathrm{HCl}(0.50 \mathrm{~mL})$ and stirred overnight at reflux. The reaction mixture was cooled to rt, extracted into ethyl acetate $(3 \times 30$ $\mathrm{mL}$ ) and washed with water. The combined organic material was dried over sodium sulphate and concentrated to dryness. Purification by silica gel chromatography eluting with 80:20 cyclohexane:ethyl acetate gave $\mathbf{4 c}$ as a white solid $\left(\mathrm{R}_{f}=0.50,36 \mathrm{mg}, 83 \%\right.$, mp. $74-75^{\circ} \mathrm{C}$, lit. $\mathrm{mp}$. 75-76 $\left.{ }^{\circ} \mathrm{C}\right) .{ }^{13}{ }^{1} \mathrm{H}$ NMR $\left(500 \mathrm{MHz}, \mathrm{CDCl}_{3}\right): \delta 7.28(\mathrm{t}, J=7.4 \mathrm{~Hz}, 2 \mathrm{H}), 7.21-7.12(\mathrm{~m}, 4 \mathrm{H}), 6.76(\mathrm{~d}$, $J=7.4 \mathrm{~Hz}, 1 \mathrm{H}), 6.68-6.63(\mathrm{~m}, 2 \mathrm{H}), 4.70(\mathrm{~s}, 1 \mathrm{H}), 2.94-2.84(\mathrm{~m}, 4 \mathrm{H}) .{ }^{13} \mathrm{C} \mathrm{NMR}(125 \mathrm{MHz}$, $\left.\mathrm{CDCl}_{3}\right): \delta 155.5,143.7,141.6,129.5,128.4,128.3,125.9,121.0,115.4,112.8,37.7,37.6$. HRMS [M] $]^{+}: 198.1060, \mathrm{C}_{14} \mathrm{H}_{14} \mathrm{O}$ requires 198.1045.

1,3-Dimethoxy-5-phenethylbenzene (4d). ${ }^{30}$ A solution of 2,2,6,6-tetramethylpiperidine $(0.25$ $\mathrm{mL}, 1.50 \mathrm{mmol})$ in THF $(20 \mathrm{~mL})$ at $-78^{\circ} \mathrm{C}$ was treated dropwise with BuLi $(2.37 \mathrm{M}, 0.69 \mathrm{~mL}$, 
$1.65 \mathrm{mmol})$ and stirred for $5 \mathrm{~min}$. $\mathrm{KOtBu}(1.0 \mathrm{M}$ in $\mathrm{THF}, 1.65 \mathrm{~mL}, 1.65 \mathrm{mmol})$ was added dropwise and stirred for $5 \mathrm{~min}$. A solution of 3,5-dimethoxytoluene $1 \mathbf{1 i}(76 \mathrm{mg}, 0.50 \mathrm{mmol})$ and toluene $1 \mathrm{a}(92 \mathrm{mg}, 1.00 \mathrm{mmol})$ in $\mathrm{THF}(5 \mathrm{~mL})$ at $-78{ }^{\circ} \mathrm{C}$ was added dropwise to the reaction mixture and stirred for $15 \mathrm{~min}$ at $-78{ }^{\circ} \mathrm{C}$. Then 1,2-dibromoethane $(0.22 \mathrm{~mL}, 2.50 \mathrm{mmol})$ was added and the mixture was stirred for a further $5 \mathrm{~min}$. The reaction mixture was warmed to rt and the solvent removed under reduced pressure. Diethyl ether $(30 \mathrm{~mL})$ was added to the residue, washed with $\mathrm{HCl}$ ( 2 M, 3 x $10 \mathrm{~mL}$ ), dried over sodium sulphate and concentrated to dryness. Purification by silica gel chromatography eluting with 96:4 cyclohexane:diethyl ether gave 4d as a colorless oil $\left(\mathrm{R}_{f}=0.40,49 \mathrm{mg}, 40 \%\right) .{ }^{1} \mathrm{H} \mathrm{NMR}\left(500 \mathrm{MHz}, \mathrm{CDCl}_{3}\right): \delta 7.29-7.26(\mathrm{~m}, 2 \mathrm{H}), 7.20$ $7.16(\mathrm{~m}, 3 \mathrm{H}), 6.36-6.29(\mathrm{~m}, 3 \mathrm{H}), 3.75(\mathrm{~s}, 6 \mathrm{H}), 2.94-2.83(\mathrm{~m}, 4 \mathrm{H}) .{ }^{13} \mathrm{C} \mathrm{NMR}\left(125 \mathrm{MHz}, \mathrm{CDCl}_{3}\right)$ : $\delta 160.7,144.2,141.7,128.4,128.3,125.9,106.5,98.0,55.2,38.2,37.6$. HRMS [M+H] ${ }^{+}$: 243.1397, $\mathrm{C}_{16} \mathrm{H}_{19} \mathrm{O}_{2}$ requires 243.1385.

1,2,3-Trimethoxy-5-phenethylbenzene (4e). ${ }^{31}$ A solution of 3,4,5-trimethoxytoluene $\mathbf{1 k}$ (91 $\mathrm{mg}$, $0.50 \mathrm{mmol})$ and toluene $1 \mathrm{a}(92 \mathrm{mg}, 1.00 \mathrm{mmol})$ in THF $(20 \mathrm{~mL})$ at $-78{ }^{\circ} \mathrm{C}$ was treated dropwise with BuLi (2.50 M, $0.66 \mathrm{~mL}, 1.65 \mathrm{mmol})$ and stirred for $5 \mathrm{~min}$. KOtBu $(1.0 \mathrm{M}$ in THF, $1.65 \mathrm{~mL}$, $1.65 \mathrm{mmol})$ was added dropwise followed by 2,2,6,6-tetramethylpiperidine $(0.25 \mathrm{~mL}, 1.50$ $\mathrm{mmol})$. The reaction mixture was stirred for $15 \mathrm{~min}$ at $-78{ }^{\circ} \mathrm{C}, 1,2$-dibromoethane $(0.22 \mathrm{~mL}$, $2.50 \mathrm{mmol}$ ) added and stirred for a further $5 \mathrm{~min}$. The reaction mixture was warmed to rt and the solvent removed under reduced pressure. Diethyl ether $(30 \mathrm{~mL})$ was added to the residue, washed with $\mathrm{HCl}$ ( $2 \mathrm{M}, 3 \times 10 \mathrm{~mL}$ ), dried over sodium sulphate and concentrated to dryness. Purification by silica gel chromatography eluting with 80:20 cyclohexane:diethyl ether gave 4e as a colorless oil $\left(\mathrm{R}_{f}=0.50,63 \mathrm{mg}, 46 \%\right) .{ }^{1} \mathrm{H} \mathrm{NMR}\left(500 \mathrm{MHz}, \mathrm{CDCl}_{3}\right): \delta 7.28(\mathrm{t}, J=7.4 \mathrm{~Hz}$, $2 \mathrm{H}), 7.21-7.15(\mathrm{~m}, 3 \mathrm{H}), 6.36(\mathrm{~s}, 2 \mathrm{H}), 3.82(\mathrm{~s}, 3 \mathrm{H}), 3.81(\mathrm{~s}, 6 \mathrm{H}), 2.94-2.84(\mathrm{~m}, 4 \mathrm{H}) .{ }^{13} \mathrm{C}$ NMR $\left(125 \mathrm{MHz}_{\mathrm{CDCl}}\right): \delta 153.0,141.6,137.4,136.3,128.5,128.3,125.9,105.5,60.8,56.1,38.3$, 37.9. HRMS $[\mathrm{M}+\mathrm{H}]^{+}:$273.1484, $\mathrm{C}_{17} \mathrm{H}_{21} \mathrm{O}_{3}$ requires 273.1491.

1,3-Dimethoxy-5-(3-methoxyphenethyl)benzene (4f) (batatasin III dimethyl ether). ${ }^{15}$ A solution of 2,2,6,6-tetramethylpiperidine $(0.25 \mathrm{~mL}, 1.50 \mathrm{mmol})$ in THF $(20 \mathrm{~mL})$ at $-78{ }^{\circ} \mathrm{C}$ was treated dropwise with $\mathrm{BuLi}(2.35 \mathrm{M}, 0.70 \mathrm{~mL}, 1.65 \mathrm{mmol})$ and stirred for $5 \mathrm{~min}$. $\mathrm{KO} t \mathrm{Bu}(1.0 \mathrm{M}$ in $\mathrm{THF}$, $1.65 \mathrm{~mL}, 1.65 \mathrm{mmol}$ ) was added dropwise and stirred for $5 \mathrm{~min}$. A solution of 3,5dimethoxytoluene 1i (76 mg, $0.50 \mathrm{mmol})$ and 3-methylanisole $\mathbf{1 f}(122 \mathrm{mg}, 1.00 \mathrm{mmol})$ in THF $(5 \mathrm{~mL})$ at $-78{ }^{\circ} \mathrm{C}$ was added dropwise to the reaction mixture and stirred for $15 \mathrm{~min}$ at $-78{ }^{\circ} \mathrm{C}$. 
Then 1,2-dibromoethane $(0.22 \mathrm{~mL}, 2.50 \mathrm{mmol})$ was added and the mixture was stirred for a further $5 \mathrm{~min}$. The reaction mixture was warmed to $\mathrm{rt}$ and the solvent removed under reduced pressure. Diethyl ether $(30 \mathrm{~mL})$ was added to the residue, washed with $\mathrm{HCl}(2 \mathrm{M}, 3 \times 10 \mathrm{~mL})$, dried over sodium sulphate and concentrated to dryness. Purification by silica gel chromatography eluting with 85:15 pentane:diethyl ether gave $4 \mathbf{f}$ as a pale yellow solid $\left(\mathrm{R}_{f}=\right.$ 0.60, $79 \mathrm{mg}, 58 \%$, mp. 41-42 $\left.{ }^{\circ} \mathrm{C}\right) .{ }^{1} \mathrm{H} \mathrm{NMR}\left(500 \mathrm{MHz}, \mathrm{CDCl}_{3}\right): \delta 7.19(\mathrm{td}, J=7.9,1.9 \mathrm{~Hz}, 1 \mathrm{H})$, 6.80-6.72 (m, 3H), 6.36-6.30 (m, 3H), $3.77(\mathrm{~s}, 3 \mathrm{H}), 3.75(\mathrm{~s}, 6 \mathrm{H}), 2.91-2.82(\mathrm{~m}, 4 \mathrm{H}) .{ }^{13} \mathrm{C} \mathrm{NMR}$ $\left(125 \mathrm{MHz}, \mathrm{CDCl}_{3}\right): \delta 160.8,159.7,144.1,143.3,129.3,120.8,114.2,111.3,106.5,98.0,55.2$, 55.1, 38.1, 37.7. HRMS [M+H] ${ }^{+}: 273.1501, \mathrm{C}_{17} \mathrm{H}_{21} \mathrm{O}_{3}$ requires 273.1491.

1,2,3-Trimethoxy-5-(3-methoxyphenethyl)benzene (4g) (aloifol I dimethyl ether). ${ }^{32}$ A solution of 3,4,5-trimethoxytoluene $\mathbf{1 k}(91 \mathrm{mg}, 0.50 \mathrm{mmol})$ and 3-methylanisole $\mathbf{1 f}(122 \mathrm{mg}, 1.00 \mathrm{mmol})$ in THF $(20 \mathrm{~mL})$ at $-78{ }^{\circ} \mathrm{C}$ was treated dropwise with BuLi $(2.50 \mathrm{M}, 0.66 \mathrm{~mL}, 1.65 \mathrm{mmol})$ and stirred for $5 \mathrm{~min}$. $\mathrm{KO} t \mathrm{Bu}(1.0 \mathrm{M}$ in $\mathrm{THF}, 1.65 \mathrm{~mL}, 1.65 \mathrm{mmol})$ was added dropwise followed by 2,2,6,6-tetramethylpiperidine $(0.25 \mathrm{~mL}, 1.50 \mathrm{mmol})$. The reaction mixture was stirred for $15 \mathrm{~min}$ at $-78^{\circ} \mathrm{C}, 1,2$-dibromoethane $(0.22 \mathrm{~mL}, 2.50 \mathrm{mmol})$ added and stirred for a further $5 \mathrm{~min}$. The reaction mixture was warmed to $\mathrm{rt}$ and the solvent removed under reduced pressure. Diethyl ether $(30 \mathrm{~mL})$ was added to the residue, washed with $\mathrm{HCl}(2 \mathrm{M}, 3 \times 10 \mathrm{~mL})$, dried over sodium sulphate and concentrated to dryness. Purification by silica gel chromatography eluting with 70:30 cyclohexane:diethyl ether gave $\mathbf{4 g}$ as a colorless oil $\left(\mathrm{R}_{f}=0.40,79 \mathrm{mg}, 52 \%\right)$. ${ }^{1} \mathrm{H} \mathrm{NMR}$ $\left(500 \mathrm{MHz} \mathrm{CDCl}_{3}\right): \delta 7.20(\mathrm{t}, J=7.8 \mathrm{~Hz}, 1 \mathrm{H}), 6.80-6.71(\mathrm{~m}, 3 \mathrm{H}), 6.37(\mathrm{~s}, 2 \mathrm{H}), 3.82(\mathrm{~s}, 3 \mathrm{H}), 3.82$ (s, 6H), $3.78(\mathrm{~s}, 3 \mathrm{H}), 2.91-2.83(\mathrm{~m}, 4 \mathrm{H}) .{ }^{13} \mathrm{C} \mathrm{NMR}\left(125 \mathrm{MHz}, \mathrm{CDCl}_{3}\right): \delta$ 159.6, 153.0, 143.2, $137.4,136.3,129.3,120.9,114.3,111.3,105.5,60.8,56.1,55.1,38.2,38.0$. HRMS [M+Na] ${ }^{+}$: 325.1409, $\mathrm{C}_{18} \mathrm{H}_{22} \mathrm{O}_{4} \mathrm{Na}$ requires 325.1416.

1,3-Dimethoxy-2,5-dimethylbenzene (5). ${ }^{33}$ A solution of 3,5-dimethoxytoluene 1i (228 mg, 1.50 $\mathrm{mmol})$ in $\mathrm{THF}(20 \mathrm{~mL})$ at $-78^{\circ} \mathrm{C}$ was treated dropwise with $\mathrm{BuLi}(2.50 \mathrm{M}, 0.66 \mathrm{~mL}, 1.65$ $\mathrm{mmol})$ and stirred for $5 \mathrm{~min} . \mathrm{KO} t \mathrm{Bu}(1.0 \mathrm{M}$ in THF, $1.65 \mathrm{~mL}, 1.65 \mathrm{mmol})$ was added dropwise, and the reaction mixture was stirred for $1 \mathrm{~h}$ at $-78^{\circ} \mathrm{C}$. Methyl iodide $(0.10 \mathrm{~mL}, 1.65 \mathrm{mmol})$ was added, and the reaction mixture was stirred at $-78{ }^{\circ} \mathrm{C}$ for $30 \mathrm{~min}$. The reaction was quenched with $\mathrm{HCl}(2 \mathrm{M}, 20 \mathrm{~mL})$, warmed to $\mathrm{rt}$ and extracted with diethyl ether $(3 \mathrm{x} 15 \mathrm{~mL})$. The combined organic layers were washed with a saturated solution of sodium thiosulphate $(2 \times 10$ $\mathrm{mL}$ ), dried over sodium sulphate and concentrated to dryness. Purification by silica gel 
chromatography eluting with 20:1 cyclohexane:diethyl ether gave $\mathbf{5}$ as a colorless solid $\left(\mathrm{R}_{f}=\right.$ 0.70, $181 \mathrm{mg}, 73 \%$, mp. $47-48{ }^{\circ} \mathrm{C}$ lit. mp. $\left.49-50{ }^{\circ} \mathrm{C}\right) .{ }^{33 b}{ }^{1} \mathrm{H}$ NMR $\left(500 \mathrm{MHz}, \mathrm{CDCl}_{3}\right): \delta 6.36$ (s, 2H), 3.80 (s, 6H), 2.33 (s, 3H), 2.05 (s, 3H). $\left.{ }^{13} \mathrm{C} \mathrm{NMR} \mathrm{(125} \mathrm{MHz,} \mathrm{CDCl}_{3}\right): \delta$ 158.2, 136.1, 111.4, 104.5, 55.7, 21.9, 7.8. HRMS [M+H] $]^{+}: 167.1069, \mathrm{C}_{10} \mathrm{H}_{15} \mathrm{O}_{2}$ requires 167.1072.

1,3-Dimethoxy-2-methyl-5-phenethylbenzene (6) (stilbostemin M). ${ }^{34}$ Solution A. A solution of 1,3-dimethoxy-2,5-dimethylbenzene $5(83 \mathrm{mg}, 0.50 \mathrm{mmol})$ in THF $(10 \mathrm{~mL})$ at $-78{ }^{\circ} \mathrm{C}$ was treated dropwise with BuLi $(2.50 \mathrm{M}$ in hexanes, $0.42 \mathrm{~mL}, 1.05 \mathrm{mmol})$ and stirred for $5 \mathrm{~min}$. $\mathrm{KO} t \mathrm{Bu}(1.0 \mathrm{M}$ in THF, $1.05 \mathrm{~mL}, 1.05 \mathrm{mmol}$ ) was added dropwise followed by 2,2,6,6tetramethylpiperidine $(84 \mu \mathrm{L}, 0.50 \mathrm{mmol})$. The reaction mixture was stirred for $15 \mathrm{~min}$ at -78 ${ }^{\circ} \mathrm{C}$. Solution B. A solution of toluene $1 \mathrm{a}(92 \mathrm{mg}, 1.00 \mathrm{mmol})$ in $\mathrm{THF}(10 \mathrm{~mL})$ at $-78{ }^{\circ} \mathrm{C}$ was treated dropwise with $\mathrm{BuLi}(2.50 \mathrm{M}, 0.44 \mathrm{~mL}, 1.10 \mathrm{mmol})$ and stirred for $5 \mathrm{~min} . \mathrm{KO} t \mathrm{Bu}(1.0 \mathrm{M}$ in THF, $1.10 \mathrm{~mL}, 1.10 \mathrm{mmol}$ ) was added dropwise followed by 2,2,6,6-tetramethylpiperidine $(0.17 \mathrm{~mL}, 1.00 \mathrm{mmol})$. The reaction mixture was stirred for $15 \mathrm{~min}$ at $-78^{\circ} \mathrm{C}$ and transferred via cannula into the solution of metalated 1,3-dimethoxy-2,5-dimethylbenzene (Solution A). The resulting mixture was immediately quenched with 1,2-dibromoethane $(0.22 \mathrm{~mL}, 2.50 \mathrm{mmol})$ and stirred for a further $5 \mathrm{~min}$ at $-78{ }^{\circ} \mathrm{C}$. The reaction mixture was warmed to $\mathrm{rt}$ and the solvent removed under reduced pressure. Diethyl ether $(30 \mathrm{~mL})$ was added to the residue, washed with $\mathrm{HCl}(2 \mathrm{M}, 3 \times 10 \mathrm{~mL})$, dried over sodium sulphate and concentrated to dryness. Purification by silica gel chromatography eluting with 98:2 pentane:diethyl ether gave $\mathbf{6}$ as a colorless solid $\left(\mathrm{R}_{f}\right.$ $=0.50,52 \mathrm{mg}, 41 \%$, mp. $77-78{ }^{\circ} \mathrm{C}$, lit. mp. $\left.77-79{ }^{\circ} \mathrm{C}\right) .{ }^{34}{ }^{1} \mathrm{H} \mathrm{NMR}\left(500 \mathrm{MHz}, \mathrm{CDCl}_{3}\right): \delta 7.30-$ $7.26(\mathrm{~m}, 2 \mathrm{H}), 7.22-7.16(\mathrm{~m}, 3 \mathrm{H}), 6.34(\mathrm{~s}, 2 \mathrm{H}), 3.77(\mathrm{~s}, 6 \mathrm{H}), 2.95-2.85(\mathrm{~m}, 4 \mathrm{H}), 2.06(\mathrm{~s}, 3 \mathrm{H}) .{ }^{13} \mathrm{C}$ NMR $\left(125 \mathrm{MHz}, \mathrm{CDCl}_{3}\right): \delta 157.2,140.8,139.2,127.5,127.3,124.9,111.0,102.9,54.7,37.4$, 37.0, 6.9. HRMS $[\mathrm{M}+\mathrm{H}]^{+}: 257.1531, \mathrm{C}_{17} \mathrm{H}_{21} \mathrm{O}_{2}$ requires 257.1542 .

2-Methyl-5-phenethylbenzene-1,3-diol (7) (stilbostemin B). ${ }^{35}$ A solution of 1,3-dimethoxy-2methyl-5-phenethylbenzene $6(30 \mathrm{mg}, 0.12 \mathrm{mmol})$ in dichloromethane $(10 \mathrm{~mL})$ at $-78{ }^{\circ} \mathrm{C}$ was treated dropwise with $\mathrm{BBr}_{3}(1.0 \mathrm{M}$ in dichloromethane, $0.70 \mathrm{~mL}, 0.70 \mathrm{mmol})$. The reaction mixture was warmed to $\mathrm{rt}$ and stirred for 3.5 hours. The reaction was then poured into a saturated solution of sodium bicarbonate $(10 \mathrm{~mL})$ and stirred vigorously for $30 \mathrm{~min}$. The product was extracted with $\mathrm{CH}_{2} \mathrm{Cl}_{2}$, washed with a saturated solution of sodium bicarbonate $(20 \mathrm{~mL})$ and brine $(20 \mathrm{~mL})$. The organic layer was dried over sodium sulphate and concentrated to dryness. Purification by silica gel chromatography eluting with 1:1 cyclohexane:ethyl acetate gave 7 as a 
colorless solid $\left(\mathrm{R}_{f}=0.70,20 \mathrm{mg}, 73 \%\right.$, mp. $152-153{ }^{\circ} \mathrm{C}$, lit. mp. $\left.153-154{ }^{\circ} \mathrm{C}\right) .{ }^{35 \mathrm{~b}}{ }^{1} \mathrm{H}$ NMR $(500$ $\mathrm{MHz}, \mathrm{CD}_{3} \mathrm{OD}$ ): $\delta 7.22$ (t, $\left.J=7.5 \mathrm{~Hz}, 2 \mathrm{H}\right), 7.17-7.10(\mathrm{~m}, 3 \mathrm{H}), 6.17$ (s, 2H), $4.81(\mathrm{~s}, 2 \mathrm{H}), 2.86-$ $2.66(\mathrm{~m}, 4 \mathrm{H}), 2.00$ (s, 3H). ${ }^{13} \mathrm{C}$ NMR (125 MHz, CD $\left.{ }_{3} \mathrm{OD}\right): \delta$ 157.1, 143.3, 141.2, 129.4, 129.2, 126.7, 109.6, 107.8, 39.0, 38.9, 8.3. HRMS [M+H] ${ }^{+}: 229.1228, \mathrm{C}_{15} \mathrm{H}_{17} \mathrm{O}_{2}$ requires 229.1229 .

Acknowledgment Science Foundation Ireland, The Irish Research Council for Science, Engineering and Technology and ERA-Chemistry are appreciated for financial support. Thanks to Dr. J. Muldoon for NMR analysis.

Supporting Information Available All ${ }^{1} \mathrm{H},{ }^{2} \mathrm{H}$ and ${ }^{13} \mathrm{C}$ NMR spectra. This material is available free of charge via the Internet

\section{References}

1. For a recent review see; Liu, C.; Jin, L.; Lei, A. Synlett 2010, 17, 2527-2536.

2. $\quad$ (a) Maji, M. S.; Murarka, S.; Studer, A. Org. Lett. 2010, 12, 3878-3881. (b) Maji, M. S.; Pfeifer, T.; Studer, A. Angew. Chem. Int. Ed. 2008, 47, 9547-9550. (c) Maji, M. S.; Studer, A. Synthesis 2009, 14, 2467-2470. (d) Krasovskiy, A.; Tishkov, A.; del Amo, V.; Mayr, H.; Knochel, P. Angew. Chem. Int. Ed. 2006, 45, 5010-5014. (e) Nishiyama, T.; Seshita, T.; Shodai, H.; Aoki, K.; Kameyama, H.; Komura, K. Chem. Lett. 1996, 549-550.

3. (a) Fleming, P.; O’Shea, D.F. J. Am. Chem. Soc. 2011, 133, 1698-1701. (b) Blangetti, M.; Fleming, P.; O’Shea, D. F. Beilstein J. Org. Chem. 2011, 7, 1249-1254. (c) Tricotet, T.; Fleming, P.; Cotter, J.; Hogan, A.-M. L.; Strohmann, C.; Gessner, V. H.; O’Shea, D. F. J. Am. Chem. Soc. 2009, 131, 3142-3143.

4. For recent reviews on the synthetic uses of mixed metal amides see; (a) Haag, B.; Mosrin, M.; Ila, H.; Malakhov, V.; Knochel, P. Angew. Chem. Int. Ed. 2011, 50, 9794-9824. (b) Mulvey, R. E. Acc. Chem. Res. 2009, 42, 743-755. For structural evidence of related lithium-potassiumTMP compositions see; (c) Armstrong, D.R.; Kennedy, A.R.; Mulvey, R.E.; Robertson, S.D. Chem. Eur. J. 2011, 17, 8820-8831.

5. (a) MacNeil, S. L.; Familoni, O. B.; Snieckus, V. J. Org. Chem. 2001, 66, 3662-3670. (b) Bates, R. B.; Ogle, C. A. J. Org. Chem. 1982, 47, 3949-3952. (c) Kaes, C.; Hosseini, W.; De Cian, A.; Fischer, J. Tetrahedron Lett. 1997, 38, 4389-4392. 
6. For alternative toluene deprotonations see; (a) Hage, M.; Ogle, C. A.; Rathman, T.L.; Hubbard, J. L. Main Group Metal Chemistry 1998, 21, 777-782. (b) Broaddus, C. D. J. Am. Chem. Soc. 1966, 88, 4174-4178. (c) Broaddus, C. D. J. Org. Chem. 1970, 35, 10-15. (d) Lochmann, L.; Petránek, J. Tetrahedron Lett. 1991, 32, 1483-1486.

7. For the use of dibromoethane as an oxidant in conjunction with transition metal catalysts see; (a) Dong, C.-G.; Yeung, P.; Hu, Q.- S. Org. Lett. 2007, 9, 363-366. (b) Nagano, T.; Hayashi, T. Chem. Lett. 2005, 34, 1152-1153.

8. Guo, D.-X.; Xiang, F.; Wang, X.-N.; Yuan, H.-Q.; Xi, G.-M.; Wang, Y.-Y.; Yu, W.-T.; Lou, H.-X. Phytochemistry 2010, 71, 1573-1578.

9. $\quad$ Alonso, F.; Riente, P.; Yus, M. Eur. J. Org. Chem. 2009, 34, 6034-6042.

10. Molander, G. A.; Yun, C.-S.; Ribagorda, M.; Biolatto, B. J. Org. Chem. 2003, 68, 55345539.

11. Jin, L.; Zhao, Y.; Zhu, L.; Zhang, H.; Lei, A. Adv. Synth. Catal. 2009, 351, 630-634.

12. For recent reviews and publications see (a) Asakawa, Y.; Ludwiczuk, A.; Nagashima, F.; Toyota, M.; Hashimoto, T.; Tori, M.; Fukuyama, Y.; Harinantenaina, L. Heterocycles 2009, 77, 99-150. (b) Gutiérrez, R. M. P. J. Med. Plant. Res. 2010, 4, 592-638. (c) Laclef, S.; Anderson, K.; White, A. J. P.; Barrett, A. G. M. Tetrahedron Lett. 2012, 53, 225-227.

13. Schultz, T. P.; Boldin, W. D.; Fisher, T. H.; Nicholas, D. D.; McMurtrey, K. D.; Pobanz, K. Phytochemistry 1992, 31, 3801-3806.

14. Yamaki, M.; Kato, T.; Bai, L.; Inoue, K.; Shuzo, T. Phytochemistry 1991, 30, 2759-2760. 15. Hernandez-Romero, Y.; Rojas, J.-I.; Castillo, R.; Rojas, A.; Mata, R. J. Nat. Prod. 2004, 67, 160-167.

16. For reviews see; (a) Schlosser, M. Mod. Synth. Methods 1992, 6, 227-271. (b) Lochmann, L. Eur. J. Inorg. Chem. 2000, 1115-1126.

17. (a) Adams, M.; Pacher, T.; Greger, H.; Bauer, R. J. Nat. Prod. 2005, 68, 83-85. (b) Kostecki, K.; Engelmeier, D.; Pacher, T.; Hofer, O.; Vajrodaya, S.; Greger, H. Phytochemistry 2004, 65, 99-106. (c) Pharmacopoeia of the Peoples Republic of China, English Edition; Chemical Industry Press: Beijing, 2000, p162.

18. (a) Song, Y.; Hwang, S.; Gong, P.; Kim, D.; Kim, S. Org. Lett. 2008, 10, 269-271. (b) Crombie, L. W.; Cromcie, W. M. L.; Firth, D. F. J. Chem. Soc. Perkin Trans. 1 1988, 1263-1270. 
(c) Tajima, R.; Oozeki, H.; Muraoka, S.; Tanaka, S.; Motagi, Y.; Nihei, H.; Yamada, Y.; Masuoka, N.; Nihei, K. Eur. J. Med. Chem. 2011, 46, 1374-1381.

19. Park, B. H.; Lee, Y. R.; Kim, S. H. Bull. Korean Chem. Soc. 2011, 32, 566-570.

20. Kofron, W. G.; Baclawski, L. M. J. Org. Chem. 1976, 41, 1879-1880.

21. Savino, T. G.; Soundararajan, N.; Platz, M. S. J. Phys. Chem. 1986, 60, 919-923.

22. (a) Sloan, M. E.; Staubitz, A.; Lee, K.; Manners, I. Eur J. Org. Chem. 2011, 4, 672-675. (b) Alonso, F.; Riente, P.; Yus, M. Tetrahedron 2009, 65, 10637-10643.

23. (a) Aitken, R. A.; Hodgson, P. K. G.; Morrison, J. J.; Oyewale, A. O. J. Chem. Soc. Perkin Trans. 1 2002, 3, 402-415. (b) Caubère, P.; Moreau, J. Tetrahedron 1970, 26, 2637-2645.

24. (a) Hannemann, K.; Wirz, J.; Riesen, A. Helv. Chim. Acta 1988, 71, 1841-1857. (b) Gilman; A. J. Org. Chem. 1963, 28, 2906-2907.

25. Azzena, U.; Pisano, L.; Antonello, S.; Maran, F. J. Org. Chem. 2009, 74, 8064-8070.

26. Fischer, F. R.; Nuckolls, C. Angew. Chem. Int. Ed. 2010, 49, 7257-7260.

27. (a) Suh, Y.; Lee, J.; Kim, S-H.; Rieke, R. D. J. Organomet. Chem. 2003, 684, 20-36. (b) Kricka, L. J.; Ledwith, A. J. Chem. Soc. Perkin Trans 1 1973, 294-297.

28. (a) Barrero, A. F.; Herrador, M. M.; Moral, J. F. Quilez del Arteaga, P.; Akssira, M.; Hanbali, F.; Arteaga, J. F.; Dieguez, H. R.; Sanchez, E. M. J. Org. Chem. 2007, 72, 2251-2254. (b) Iyoda, M.; Sakaitani, M.; Otsuka, H.; Oda, M. Chem. Lett. 1985, 127-130.

29. Esumi, T.; Wada, M.; Mizushima, E.; Sato, N.; Kodama, M.; Asakawa, Y.; Fukuyama, Y. Tetrahedron Lett. 2004, 45, 6941-6946.

30. Molander, G. A.; Sandrock, D. L. Org. Lett. 2009, 11, 2369-2372.

31. Asakawa, Y.; Hashimoto, T.; Takikawa, K.; Tori, M.; Ogawa, S. Phytochemistry 1991, 30, 235-251.

32. Juneja, R. K.; Sharma, S. C.; Tandon, J. S. Phytochemistry 1987, 26, 1123-1126.

33. (a) Azzena, U.; Denurra, T.; Melloni, G.; Piroddi, A. M. J. Org. Chem. 1990, 55, 53865390. (b) Ridley, D. D.; Ritchie, E.; Taylor W. C. Aust. J. Chem. 1968, 21, 2979-2988.

34. Yang, X.; Lin, L.; Tang, C.; Liu, Y.; Ye, Y. Helv. Chim. Acta 2007, 90, 318-325.

35. (a) Zhao, W.; Qin, G.; Ye, Y.; Xu, R.; Le, X. Phytochemistry 1995, 38, 711-714. (b) Pacher, T.; Seger, C.; Engelmeier, D.; Vajrodaya, S.; Hofer, O.; Greger, H. J. Nat. Prod. 2002, 65, 820-827. 